IZA DP No. 6139

Decline in Social Mobility:

Unfulfilled Aspirations among Egypt's Educated Youth

Christine Binzel

November 2011 


\title{
Decline in Social Mobility: Unfulfilled Aspirations among Egypt's Educated Youth
}

\author{
Christine Binzel \\ University of Heidelberg \\ and IZA
}

Discussion Paper No. 6139

November 2011

\author{
IZA \\ P.O. Box 7240 \\ 53072 Bonn \\ Germany \\ Phone: +49-228-3894-0 \\ Fax: +49-228-3894-180 \\ E-mail: iza@iza.org
}

\begin{abstract}
Any opinions expressed here are those of the author(s) and not those of IZA. Research published in this series may include views on policy, but the institute itself takes no institutional policy positions.

The Institute for the Study of Labor (IZA) in Bonn is a local and virtual international research center and a place of communication between science, politics and business. IZA is an independent nonprofit organization supported by Deutsche Post Foundation. The center is associated with the University of Bonn and offers a stimulating research environment through its international network, workshops and conferences, data service, project support, research visits and doctoral program. IZA engages in (i) original and internationally competitive research in all fields of labor economics, (ii) development of policy concepts, and (iii) dissemination of research results and concepts to the interested public.
\end{abstract}

IZA Discussion Papers often represent preliminary work and are circulated to encourage discussion. Citation of such a paper should account for its provisional character. A revised version may be available directly from the author. 


\section{ABSTRACT \\ Decline in Social Mobility: Unfulfilled Aspirations among Egypt's Educated Youth*}

This paper studies how the gradual suspension of an employment guarantee scheme for secondary and post-secondary graduates has affected intergenerational mobility across welleducated cohorts in Egypt. The empirical results support suggestive evidence in the Middle East of a decline in social mobility among the increasingly well-educated youth. The results further indicate that unequal opportunities are due to difficulties in attaining high-level occupations in the formal private sector for graduates from a lower socio-economic background, and that personal connections may play a decisive role. Thus, aside from credit market imperfections, labor market constraints may be important in explaining low social mobility.

JEL Classification: J62, J24, O10

Keywords: intergenerational mobility, Islamic revival, schooling, labor market

Corresponding author:

Christine Binzel

Department of Economics

University of Heidelberg

Bergheimer Str. 20

69115 Heidelberg

Germany

E-mail: christine.binzel@awi.uni-heidelberg.de

\footnotetext{
* Conversations with and comments from Ragui Assaad, Abigail Barr, Carlos Bozzoli, Tilman Brück, Jean-Paul Carvalho, Dietmar Fehr, Paul Glewwe, Paul Gregory, Marwan Khawaja, Dorothea Kübler, Thomas Siedler, Douglas Staiger, Viktor Steiner, Francis Teal and Gaston Yalonetzky greatly improved the paper. This paper has also benefited from comments from seminar participants at IZA, Dartmouth College, CSAE in Oxford, DIW Berlin, Goethe University Frankfurt, the Berlin Network of Labour Market Research (BeNA) and from participants at the 2011 NEUDC Conference, the 2011 Annual Conference of the German Economic Association, the 2011 EEA Meetings, the 2010 AEL Conference on Development Economics and Policy and the 2009 Doctoral Workshop on Development Economics at IZA/Bonn. The usual disclaimer applies.
} 


\section{Introduction}

Empirical studies of intergenerational mobility suggest that the transmission of economic status across generations is higher in less developed countries than in developed ones (for reviews, see Björklund and Jäntti, 2000; Grawe and Mulligan, 2002; Solon, 2002; Corak, 2004). That is, with economic development, and particularly with expansion of the educational system, a country's social mobility will increase. Evidence from the Middle East, however, suggests that this may not always be the case. Contrary to other developing regions (e.g. Jensen, 2010; Barro and Lee, 2010), education and labor market policies in the Middle East have generally been associated with high demand among the population for higher levels of education. This is said to have led to a tremendous increase in educational attainment across social strata. Yet, instead of observing an increase in economic mobility across generations, a widespread narrative in the Middle East has been that of a decline in social mobility among the increasingly well-educated youth (e.g. Wickham, 2002; Carvalho, 2010). Quantitative, microeconomic data to test this claim has not been available.

In the middle of the last century, Arab countries overall started out with low levels of education. Since then, progress has been rapid despite their comparatively slow fertility decline (Richards and Waterbury, 2008). At the same time, Middle Eastern governments felt responsible for providing employment to those with intermediate or higher education who were unable to find a job in the private sector, partly out of fear of political unrest among the urban youth (e.g. Mazumdar, 1989; Salehi-Isfahani, 2007). In turn, the public sector was, and still is, large in many Middle Eastern countries (Richards and Waterbury, 2008). This "last resort" option, which had been turned into formal job guarantee schemes in Morocco and Egypt, quickly became the principal driver of household investment in education, given the high pay in the public sector and non-wage benefits, such as job stability and social security (Assaad, 1997; SalehiIsfahani, 2007). While public sector jobs became less available since the mid-1980s, the marginalized and highly regulated private sector has been incapable of absorbing the growing ranks of educated youth, pushing more and more of the educated young people into unemployment and the informal sector (World Bank, 2004b; Assaad, 2007, 2009). ${ }^{1}$ Consequently, the reduction in employment opportunities in the formal sector has created fiercer competition among the well educated, raising the question of who

\footnotetext{
${ }^{1}$ Compared internationally, youth unemployment is highest in the Middle East and North African region (World Bank, 2004b; Dhillon, Dyer and Yousef, 2009). Economic underperformance, coupled with increased levels of schooling, is also viewed as a main driver of the Middle East's Arab Spring (Campante and Chor, 2011).
} 
manages to obtain one of the relatively scarce "respectable" jobs.

This paper uses nationally-representative household survey data from Egypt, the most populous Arab country, whose social, political, and economic developments has played a central role in the region. Egypt introduced its employment guarantee scheme for secondary school and university graduates in the early 1960s. However, the scheme became increasingly untenable in the 1980s, and, since the early 1990s, basically became defunct (Assaad, 2007). This study makes use of this policy change and analyzes how the suspension of the employment guarantee scheme and, thereafter, the rapid decline in formal (public) sector employment, affected social mobility, by comparing intergenerational mobility for graduates born in the 1950s (i.e. 1949-1960, "old cohort") as opposed to those born in the 1970s (i.e. 1968-1977, "young cohort").

The findings in this paper generally support suggestive evidence in the Middle East of a decline in social mobility among the increasingly well-educated youth. Whereas university graduates born in the 1950s faced equal opportunities on the labor market, this is not the case for graduates born 20 years later: university graduates from a high socio-economic background are significantly more likely to attain a professional occupation in the formal sector, thus disproportionally leaving the inferior occupations and jobs to those from lower socio-economic backgrounds. This change over time is also economically significant: for the more recent cohort of graduates, having a father working as professional increases a graduate's probability to attain a professional occupation by about 20 percentage points as compared to the old cohort of graduates. The empirical results further suggest that this decline in mobility is linked to how jobs are allocated in the formal private sector and that personal connections, in particular, may play an important role.

The finding of a decline in social mobility among the educated is important in several ways. First, the predominant explanation in the theoretical literature for a high persistence of income or wealth across generations is that of credit market imperfections, which constrain low-income families from investing in the human capital of their children (e.g. Loury, 1981; Becker and Tomes, 1986; Mookherjee and Ray, 2002). Such credit market imperfections particularly constrain households in developing countries, which face imperfections in other markets as well (e.g. Rosenzweig and Wolpin, 1993; Udry, 1995) and are vulnerable to risks from a variety of sources, such as illness and drought (e.g. Morduch, 1995). This reasoning has led some researchers to use intergenerational educational mobility estimates as a proxy for economic mobility across generations, since earnings and occupational data regarding parents are often not available from surveys conducted in developing countries or the data do not allow controlling for potential life 
cycle effects (e.g. Binder and Woodruff, 2002; Hertz et al., 2007; Louw, van der Berg and Yu, 2007; Hertz, Meurs and Selcuk, 2009). Among the few studies that use earnings or occupational data from developing countries are Valero-Gil and Tijerina-Guajardo (2002) on Mexico, Grawe (2004) on Ecuador, Nepal, Pakistan, and Peru, Dunn (2007) on Brazil, and Ng (2007) on Malaysia. As the empirical results of this paper illustrate, while increased access to education may be a necessary condition for increased economic mobility across generations, it is not a sufficient one.

Second, and relatedly, this paper makes a contribution to the rekindled debate about why educational policies - that is, the expansion of the educational system - have not been more effective in promoting economic growth in developing countries (Pritchett, 2001; Hanushek and Woessmann, 2007). One response among scholars has been to shift from simply considering years of schooling to more closely examining school quality and to recognizing the importance of cognitive skills. The findings of this paper suggest a potential additional impediment to growth: the functioning of the labor market. In Egypt - and presumably Middle Eastern countries more generally (compare World Bank, $2004 b$ ) - the dominance of the public sector and the high degree of regulation in the private sector have constrained the labor market's ability to absorb newly-skilled labor market entrants and to make use of their skills. As the empirical findings indicate, it is only when employment opportunities become scarce that a graduate's parental background begins to play a role, to the extent that, for many, increased educational achievement has not translated to corresponding economic outcomes.

Finally, this paper provides an important piece of evidence that is missing in the literature on the Islamic revival. This literature argues that one of the main drivers for the tremendous rise in Islamic devotion and activism throughout the Middle East over the past few decades is the combination of increased access to education, which has raised expectations moving up socially among youth and their families, and reduced social mobility among the well-educated (e.g. Bayat, 2002; Wickham, 2002; Farah, 2009; Carvalho, 2010). ${ }^{2}$ More specifically, the reasoning is that the reduction in public sector employment since the 1980s has disproportionally affected educated youth from a lower socio-economic background, as getting a formal job in the private sector requires having the right personal connections and/or additional skills acquired in the private education sector, such as a foreign language skill, that these graduates do not have (Salmi, 1990; Wickham, 2002). The fact that unfulfilled aspirations among these graduates have

\footnotetext{
${ }^{2}$ For an extensive review of the literature and a theoretical model of the Islamic revival, see Carvalho (2010). Carvalho's analysis further suggests that an increase in income inequality and impoverishment of the lower-middle class has contributed to the Islamic revival in the region.
} 
stemmed from reduced social mobility has created, in turn, fertile ground for Islamic groups to recruit followers. ${ }^{3}$ As argued by Carvalho (2010, p. 2), "religious values not only de-emphasize material comparisons, they also accentuate moral comparisons." Adherence to Islamic values has enabled graduates from a lower socio-economic background to compete with those from an elite background (i.e. from the upper or upper middle class) on a moral playing field. ${ }^{4}$

The empirical analysis is restricted to males, given the continued low female labor force participation in Egypt of under 30\% (Egypt Labor Market Panel Survey of 2006, ELMPS06). ${ }^{5}$ A graduate's social status can be measured through his father's occupation; therefore, this study examines whether the association between the occupations of fathers and sons has increased significantly across cohorts of the well educated. This quantitative, microeconomic analysis is made possible through the cross-section of the 2006 Egypt Labor Market Panel Survey (ELMPS06), which provides information not only about the educational attainment of fathers and sons, but also about their occupations. Importantly, employment history information for the sons allows one to account for potential life-cycle effects that may impact intergenerational mobility estimates. In the case of wage employment, the ELMPS06 also asked respondents questions about the employment sector and the formality of their job, i.e. whether the job entailed a work contract and social insurance. Hence, alternative outcome measures can be used to examine the robustness of the results and to learn about the sources of change in intergenerational mobility. In addition, information about fathers' and sons' educational attainment is used to study whether the expansion of the educational system indeed led to an increase in intergenerational educational mobility, enabling children across the

\footnotetext{
${ }^{3}$ This grievance-based explanation provides one part of the story - specifically, why the Islamic movement has been driven by the educated. As Wickham (2002) convincingly argues, in an authoritarian regime, like that of Egypt, the decentralized structure of the Islamic movement, which recruited first followers from the "periphery" of the formal political system, has also played a crucial role in mobilizing many educated, young people.

${ }^{4}$ The idea may be related to one of the findings by Campante and Chor (forthcoming), namely, that if the returns to education are low in the labor market, individuals divert their skills to other (i.e. political) activities. In the case of Egypt and other authoritarian regimes in the Middle East, religious groups seem to have created an alternative arena where individuals can exercise their skills. Unfortunately, the dataset at hand does not allow testing of this claim. The 2000 and 2008 World Values Survey (WVS) data from Egypt, however, provide some weak evidence, namely that university graduates from a lower socio-economic background attend religious services more frequently than those from the upper (middle) class.

${ }^{5}$ Over the past decades, female market labor force participation only slowly increased, from $12 \%$ in 1986 (Richards, 1992, p. 4) to slightly over $20 \%$ in the 1990 s and finally to $27 \%$ in 2006 (Assaad and El Hamidi, 2009). With jobs in the government sector declining, women - particularly the highly educated - faced increased difficulties obtaining "appropriate" jobs (Assaad and El Hamidi, 2009). Gender segregation in the labor market remaines high (World Bank, 2004a) and many women stop working after marriage (e.g. Hoodfar, 1997).
} 
social strata to achieve secondary and post-secondary degrees.

The remainder of this paper is organized as follows: section 2 summarizes how the Egyptian educational system and the labor market changed since the middle of the 20th century. Section 3 presents a conceptual framework, while sections 4 and 5 discuss the methods and the data, respectively. In section 6, the empirical results are presented, and section 7 concludes.

\section{Background}

Educational and labor market policies over the past half century must be viewed against Egypt's high population growth. Egypt's population increased from 22 million in 1950, to 40 million in 1975 and 77 million in 2005 (UN Population Database). Population growth alone has placed severe pressures on both the school system and labor market. In the following, the main trends first in education and then in the labor market will be sketched (for details see, amongst others, World Bank, 1991; Richards, 1992; Assaad, 1997; Hargreaves, 1997; UNDP, 1998, 2000; Assaad, 2009).

\subsection{The Expansion of the Schooling System}

The expansion of the general schooling system began with the 1952 revolution under Gamal Abdel Nasser (Salmi, 1990). Because of the Suez crises in 1956 and several wars in the 1960s and 1970s, resources were limited and the government introduced double and sometimes even triple shifts in primary schools in the early 1960s (Nagi, 2001). Between 1952 and 1965-6, primary education experienced an enrollment growth rate of almost $9 \%$ per annum (Richards, 1992, p. 8). ${ }^{6}$ Among the population aged 10 and above, illiteracy rates fell from $85.2 \%$ in 1937 to $70.5 \%$ in 1960 and 57.2\% in 1976 (World Bank, 1991, p. 207). Secondary and post-secondary education expanded even more rapidly. Between 1960 and 1980, enrollment growth rates for secondary education averaged at $15 \%$ per annum (Salmi, 1990, p. 96). In 1963, following the abolishment of fees for primary and secondary schools, university fees were also abolished. Under Anwar El Sadat (19701981), policies to expand educational access continued. Several new universities were established in the 1970s (Shann, 1992), and university enrollment increased by over 14\% per annum between 1971 and 1977 (World Bank, 1991, p. ii). However, access to university education became more restrictive in the 1980s and early 1990s in an effort to limit the supply of university graduates (compare Assaad, 2007). Instead, the

\footnotetext{
${ }^{6}$ Between 1988 and 1999, primary education was reduced from 6 to 5 years (Salehi-Isfahani, Tunali and Assaad, 2009). This policy change does not, however, affect, the cohorts considered in this paper.
} 
government put a greater emphasis on technical/vocational secondary education (Salmi, 1990).

In Egypt, students bound for university are placed on a separate educational track when entering secondary school, i.e. around the age of 15 (Salehi-Isfahani, Tunali and Assaad, 2009). Only students with high scores in the national exam taken at the end of preparatory school are allowed to enter so-called "general secondary schools." All other students may enter technical/vocational secondary schools, which include a large commercial branch and which typically last three years; some last five. Admission to university as well as to a particular course of study depends on the results of an examination taken at the end of the general secondary school, called the thanaawiya aama (Hargreaves, 1997). Only the best students are allowed to study medicine or engineering; those with lower grades may "only" become teachers. There is evidence that students (and their families) prefer university over vocational education even though earnings are not necessarily higher (Salmi, 1990). One explanation is the low status attached to such technical schools; typically students who attend them previously failed to enter the university track (Salmi, 1990; Richards, 1992). More generally, education is highly valued in society and in the marriage market in particular, so that potential earnings are not the only concern (e.g., Salmi, 1990; Hoodfar, 1997). Another explanation is that a university diploma is important for obtaining a professional, formal job. Thus, even while the chances of obtaining such a job have declined, families may prefer not to forego the opportunity altogether (Salmi, 1990; Hargreaves, 1997).

There is ample evidence that private costs to education, in particular for private lessons, have been increasing over the last two to three decades (Richards, 1992; Hargreaves, 1997; UNDP, 1998, 2000). Policies in the 1980s that introduced exams and reduced the ability to students to repeat grades at the end of primary and preparatory school education have been one reason for this increase (e.g. Hanushek and Lavy, 1994). Furthermore, as real wages have been deteriorating since the mid-1980s, private tutoring - albeit still illegal - has become an extra source of income for teachers (UNDP, 1998). These developments might also explain why a relatively high percentage of men in the young cohort have failed to obtain any formal educational degree. It could also be an additional driver of limited mobility at the top of the educational distribution, as low-income families are likely to lack the financial resources for extensive private tutoring. 


\subsection{The Employment Guarantee Scheme and its Legacies}

Socialist policies led to the nationalization of Egypt's industries in the 1960s (World Bank, 1991). In 1961, the government introduced an employment guarantee scheme for university graduates, and in 1964, extended it to include secondary school graduates (Assaad, 1997; Handoussa and El Oraby, 2004). The employment guarantee scheme is a reflection of the patron-client relationship, or "social contract", between the Egyptian state and its citizens (e.g. Bayat, 2002; Richards and Waterbury, 2008). The state perceives itself as the provider of jobs and welfare benefits (including a wide range of subsidies). In return for these services, Egyptian leaders expected political support. Since jobs in the government sector have traditionally meant high job stability, social insurance, access to subsidized goods and accommodations as well as other benefits (Assaad, 1997), the demand for higher education increased sharply with the introduction of this employment scheme, as did the number of applicants for government sector jobs.

Due to the high economic growth rates following the oil boom, revenues from the Suez Canal and high remittance flows, the employment guarantee scheme survived the 1970s. On average, the Egyptian economy grew at a rate of $9 \%$ per annum between 1974 and 1981 (World Bank, 1991, p. 43). Labor supply pressures were partly reduced because of Sadat's open door policy, under which, by some estimates, about $10 \%$ of the labor force was abroad, particularly in Saudi Arabia, Kuwait, the United Arab Emirates, Qatar and Iraq (for a discussion see Sell, 1988; Kandil and Metwally, 1992). Nevertheless, over time, the employment guarantee scheme became more and more untenable (for details see Assaad, 1997; Handoussa and El Oraby, 2004). From 1978 onward, the government allowed public enterprises to circumvent the employment guarantee scheme. Public sector employees were also offered to take unpaid leave in order to work in the private sector. Nevertheless, by 1982-3 government employment was triple the level witnessed in 1966 (Richards, 1992, p. 33, based on Handoussa 1988). When Hosni Mubarak (1981-2011) came into power, the employment guarantee scheme was not immediately abolished. A number of changes to the scheme were made, however, including increased waiting periods for jobs in the government sector, particularly for secondary school graduates. By the end of the 1980s, the waiting period was more than five years. Moreover, wages in the public sector deteriorated in real terms. Despite these changes, in the 1990s still many lined up for government sector jobs due to the extra benefits they provided. Given the short working hours in government agencies, many workers made up for low wages by moonlighting after work. The mass private-sector resignations that occurred when the government decided in 1992 to take graduates with a private sector job off 
the government-job registry is one clear example of the public's strong preference for public sector work. Wickham (2002, p. 57) also notes that among the graduates she interviewed, manual occupations were seen as a last (and temporary) resort only.

In 1991, Egypt adopted the Economic Reform Structural Adjustment Program, a program supported by the International Monetary Fund and the World Bank (Korayem, 1997). While labor market policies were introduced in the 1990s to make the economy more competitive, it was only in 2003 that rigid labor market regulations on hiring and firing were truly relaxed (Salehi-Isfahani, Tunali and Assaad, 2009). With a declining government sector and a constrained private sector, unemployment rates were highest for men with a technical secondary-school degree in both 1988 and 1998, particularly in rural areas (Assaad, 2009). Furthermore, an increasing percentage of well-educated labor market entrants have been forced to take up jobs in the informal sector or work unpaid for the family (Amer, 2009; Assaad, 2009; Assaad, Binzel and Gadallah, 2010). These labor market developments have also been aggravated by reduced employment opportunities in the Gulf that used to cushion labor supply pressures in Egypt, especially in the 1970s and early 1980s (Kandil and Metwally, 1992; Aly and Shields, 1996; Wickham, 2002).

By comparing men born in 1949-1960 (old cohort) and men born in 1968-1977 (young cohort), one can evaluate the overall effect of these changes in the educational system and the labor market on intergenerational mobility. Those born between 1949 and 1960 were the first to benefit from the expansion of the educational system with free schooling across all educational levels. ${ }^{7}$ Men of the older cohort were also eligible for the employment guarantee scheme, provided that they had succeeded in achieving a secondary or post-secondary degree. On the other hand, men born between 1968 and 1977 were confronted with very different labor market conditions when they entered the labor market in the 1990s - in particular, the employment guarantee scheme was only partially in effect. Despite declining opportunities in the government sector, the private sector remained highly regulated.

\section{Conceptual Framework}

The narrative of this paper is that Egypt's employment guarantee scheme created aspirations among families from a low socio-economic background for moving up socially by investing in the education of their children, but that these aspirations have, to some extent, remained unfulfilled, due to the gradual suspension of the scheme in the 1980s,

\footnotetext{
${ }^{7}$ Note that at age 15 it is already decided whether a child will enter a university or a technical/vocational track.
} 
which has led to a decline in social mobility. ${ }^{8}$

To formalize this idea, suppose that there are only two schooling levels, $S=\{0,1\}$. For illustration, assume that $S=0$ refers to less than a university education, while $S=1$ refers to a university education. Also, there are only two occupational outcomes, high (say, professional; $h$ ) and low (say, other non-manual and manual occupations; $l$ ). Parents decide whether or not to invest in their child's schooling. Without schooling $(S=0)$, their child obtains a low-level occupation. With schooling $(S=1)$, their child obtains a high-level occupation with probability $P$, or a low-level occupation, with probability $1-P$. Conditional on $S=1$, it is assumed that this probability depends solely on the child's socio-economic background, or status.

Suppose that there are two time periods, $t=\{1,2\}$. In the first time period, parents decide whether or not to invest in their child's schooling, while in the second, their child reaps any benefits of the schooling investment. Then, in $t=1$, parents choose to invest in their child's schooling if

$$
P_{t=1} Y_{h}+\left(1-P_{t=1}\right) Y_{l}-C \geq Y_{l}
$$

where $C$ refers to schooling costs and $Y_{h}\left(Y_{l}\right)$ to the benefits associated with a high-level (low-level) occupation. Note that such benefits might include not only earnings, but also less tangible job perquisites, such as having a formal job and social status. ${ }^{9}$ That is, parents choose to provide their child with a university education if the net expected payoff is greater than the payoff for a low-level occupation, which their child would otherwise attain. Recall that having invested in schooling does not necessarily assure securing a high-level occupation: securing a high-level occupation depends on the probability $P$. An implicit assumption being made is that parents have full information about the occupational outcomes of educated youth who enter the labor market in the same time period in which they make the schooling decision for their child, i.e. in $t=1$, as well as the socio-economic background of the young graduates. Because parents cannot look into the future, they use this information to determine the probability $P_{t=1}$, which constitutes their best prediction for the actual, ex-post probability that their child will face when leaving school in period $t=2\left(P_{t=2}\right)$. Note that if the probability of securing a high-level occupation is the same for children from different socio-economic backgrounds, a child's

\footnotetext{
${ }^{8}$ The framework presented in this section has similarities to the Roy model as described in Heckman, Lochner and Todd (2006).

${ }^{9}$ While private costs for (public) schooling have increased in Egypt, lower income households have tried to afford the schooling costs of at least one of their sons to ensure a stable (even if not particularly high) income stream as well as to gain access to goods and services that used to accompany a government sector job (see also section 2).
} 
labor-market outcome is independent of his socio-economic background, implying equal opportunities in the labor market. ${ }^{10}$

Note that, for simplicity, schooling costs $(C)$, the value of a high-level occupation $\left(Y_{h}\right)$, and the value of a low-level occupation $\left(Y_{l}\right)$ are assumed to be fixed over time. Rewriting the above condition then gives the following schooling choice which parents face:

$$
S= \begin{cases}1 & \text { if } P_{t=1}\left(Y_{h}-Y_{l}\right) \geq C \\ 0 & \text { otherwise }\end{cases}
$$

Since in the worst case scenario, i.e. with probability $1-P_{t=1}$, an educated child (with $S=1$ ) will attain a low-level occupation, the additional benefit from having a highlevel occupation times the probability of achieving it needs to exceed schooling costs for parents to invest in their child's schooling.

In period $t=2$, the child realizes his payoff,

$$
U=S\left[P_{t=2} Y_{h}+\left(1-P_{t=2}\right) Y_{l}\right]+(1-S) Y_{l}
$$

If parents choose not to invest in their child's schooling in period $t=1, U=Y_{l}$, i.e. the child receives the benefit of a low-level occupation in the following period. In contrast, if parents invest in their child's schooling, so that $S=1$, the child faces a new probability of securing a high-level occupation in $t=2, P_{t=2}$. Given that $Y_{h}$ and $Y_{l}$ are assumed to be time-invariant, differences in a child's ex-ante and ex-post payoffs - or, returns to education - depend solely on $P_{t=1}$ and $P_{t=2}$, respectively. ${ }^{11}$

As stated earlier, it is assumed for simplicity that, conditional on having invested in education, $P$ depends solely on a child's socio-economic background. Suppose that the society we are concerned with consists of only two distinct socio-economic classes, labeled high and low. Then, social mobility declines if

$$
\begin{gathered}
P_{\text {high }, t=2}-P_{\text {low }, t=2}>P_{\text {high }, t=1}-P_{\text {low }, t=1}, \text { or } \\
P_{\text {high }, t=2}-P_{\text {high }, t=1}>P_{\text {low }, t=2}-P_{\text {low }, t=1} .
\end{gathered}
$$

That is, the probability of achieving a high-level occupation decreases more strongly (or, increases less) over time for educated children from a low socio-economic background

\footnotetext{
${ }^{10} \mathrm{An}$ implicit assumption is that besides the formal educational degree, personality traits and other individual characteristics are randomly assigned, i.e. are not correlated with social class. Similar assumptions have been made in the related theoretical literature (e.g. Loury, 1981).

${ }^{11}$ For the distinction between ex-ante and ex-post returns to education see Heckman, Lochner and Todd (2006).
} 
relative to educated children from a high socio-economic background. Or, alternatively, graduates from a high socio-economic background become more likely over time to attain a high-level occupation compared to their counterparts from a low socio-economic background.

With regard to Egypt, changes in these probabilities have been triggered by a combination of reduced employment opportunities - reducing both $P_{\text {high }}$ and $P_{\text {low }}$ - and advantages enjoyed by graduates from a higher socio-economic background, namely: (1) personal connections, called wasta (Wickham, 2002, p. 55); and (2) financial resources that enable them to acquire additional skills offered by the private education sector. These advantages can be interpreted as changing the relationship between $P_{h i g h}$ and $P_{\text {low }}$ over time. Testing whether this relative change in probabilities is statistically and economically significant is the aim of the empirical analysis. Note that the dataset does not allow one to discriminate between different sources of the decline in social mobility across cohorts, even though some evidence will be provided that personal connections do appear to play a role. $P$ thus captures factors outside the formal educational degree a child has acquired.

Comparing the cohorts 1949-1960 and 1968-1977 thus has two purposes: first, when parents of the young cohort (1968-1977) made the schooling decision for their children, they based their expectations about the ex-post returns to education for their children - more specifically, the probability of attaining a high-level occupation, $P_{t=2}$ - on the labor market experiences of the old cohort (1949-1960). In particular, the old cohort benefited from the employment guarantee scheme. Since there was no sign at that time that the scheme would soon be abolished, many low-income parents of the young cohort decided to invest in their child's education. Hence, by comparing the probabilities for these two cohorts, one can infer whether, for graduates of the young cohort, the ex-post returns to education are below their ex-ante returns to education due to a decline in social mobility, and thus, whether aspirations among those from a low socio-economic background remain unfulfilled. (Recall that in the framework presented here, changes in the returns to education depend solely on changes in $P ; Y_{h}$ and $Y_{l}$ are assumed to be time-invariant.) Second, as argued in section 2, it allows one to evaluate how the decline in government sector employment has affected social mobility.

\section{Empirical Approach}

The main part of the empirical analysis aims at testing whether, conditional on having achieved a certain educational degree, the probability of attaining a high-level occupa- 
tion has changed across the social strata over time, i.e. whether inequality (4) holds. By measuring an individual's socio-economic background through his father's occupational attainment, the empirical analysis can essentially be viewed as examining how intergenerational occupational mobility has changed across well-educated cohorts. That is, the sample is restricted to men of the old cohort (born 1949-1960) and the young cohort (born 1968-1977) who achieved at least a university or a comparable degree (i.e. a post-secondary degree). The empirical model is summarized by the following equation:

$$
\begin{aligned}
P(\operatorname{Prof}=1)=\alpha_{0}+\alpha_{1} \operatorname{Prof}^{f a}+\alpha_{2} Y n g+\alpha_{3}\left(\operatorname{Prof}^{f a} \times Y n g\right)+ & \\
& \alpha_{4} U \text { rban }+Y r B i r t h \boldsymbol{\gamma}+\nu
\end{aligned}
$$

where $P(\operatorname{Prof}=1)$ refers to the son's probability of attaining a professional occupation or, more generally, a non-manual occupation, which includes white collar occupations. Alternatively, for wage workers, information about the characteristics of the job, namely the formality of the job and the sector of employment (public versus private) is used. For the old cohort, non-manual, formal jobs essentially meant having a government sector job, given that the private sector at that time was almost non-existent. For the young cohort, we would expect to observe instead - and we do - a higher share of men with formal jobs in the private sector. Further, if the higher-paid formal jobs are indeed increasingly located in the private sector and require personal connections or additional skills, such as the knowledge of foreign languages, we should not observe a decline in mobility if the outcome of interest is employment in the government sector.

Life-cycle effects are controlled for by comparing the occupational outcomes of sons at a specific age. For reasons explained in the following section, the son's occupation at age 28 is used. ${ }^{12}$ In the simplest specification, $P r o f^{f a}$ is a binary variable indicating whether the father worked as a professional. Hence, in terms of the conceptual framework, $\alpha_{1}$ gives an estimate of $P_{\text {high }}-P_{\text {low }}$ in $t=1$. Alternatively, five occupational categories are distinguished, namely professional, white-collar, skilled manual workers, semi/unskilled manual workers and farmers (see also next section). $Y n g$ is a dummy for belonging to the young cohort (i.e. sons born in 1968-1977), YrBirth stands for the son's year of birth dummies, and Urban is a binary variable indicating urban residence at birth.

To assess changes in $P_{\text {high }}-P_{\text {low }}$ across cohorts (over time), an interaction term between Prof ${ }^{f a}$ and $Y n g$ is included. Under the employment guarantee scheme, parental background should not have played any role, i.e. $\alpha_{1}$ is expected to be statistically

\footnotetext{
${ }^{12}$ As explained in the following section, the data do not allow one to control for potential life-cycle effects with regard to fathers, which should not, however, constitute a serious drawback.
} 
insignificant, while for graduates of the young cohort, having a father working as a professional is expected to increase the son's likelihood of also working as a professional. That is, the main hypothesis is that $\alpha_{3}$ is positive and statistically significant.

The sociological literature has largely paid attention to university graduates. Since the employment guarantee scheme also applied to secondary school graduates, the sample is alternatively restricted to men with secondary school degrees and higher, in order to examine the sensitivity of the results. Note that conditioning on the son's educational attainment eliminates the complication that correlations between father and son occupations may be based on the son's human capital investment, at least in terms of the formal degree achieved.

An alternative way to study the creation of unfulfilled aspirations is to examine whether the (occupational) return to a university degree has declined over time for men from a low, relative to a high, socio-economic background. This corresponds to estimating the following equation, using a similar set of covariates as before, but drawing on the full sample:

$$
\begin{aligned}
P(\operatorname{Prof}=1)=\alpha_{0}+E d u \boldsymbol{\beta}+\alpha_{1} Y n g+(E d u \times Y n g) \boldsymbol{\eta}+ & \\
\alpha_{2} \operatorname{Prof}^{f a}+\left(E d u \times \operatorname{Prof}^{f a}\right) \boldsymbol{\lambda}+(E d u \times & \text { Prof } \left.f^{f a} \times Y n g\right) \boldsymbol{\delta}+ \\
& \alpha_{3} U r b a n+Y r B i r t h \boldsymbol{\gamma}+\nu,
\end{aligned}
$$

where $E d u$ stands for dummies for the highest educational degree attained (primary or preparatory degree, secondary degree, and post-secondary degree; the reference category being "no degree"). The coefficient estimates on the first interaction terms, $\boldsymbol{\eta}$, will reveal whether the occupational return to university education (relative to having no educational degree) decreased over time for men whose father is not working as a professional. In contrast, the coefficient estimates on the last interaction terms, $\boldsymbol{\delta}$, allow one to directly test whether the occupational return to a university degree has increased for graduates from a high, relative to a low, socio-economic background.

\section{Data}

The empirical analysis draws on the 2006 cross-section of the Egypt Labor Market Panel Survey (ELMPS06). 8,349 households (consisting 37,140 individuals) were captured in this nationally representative survey in 2005-06. Of this number, 3,684 households had been previously interviewed in the 1998 survey wave and 2,167 households represented splits from these. The remaining 2,498 households were new (refresher sample). Unless 
Table 1: Summary Statistics for Men Born 1949-60 ("Old Cohort") and 1968-1977 ("Young Cohort").

\begin{tabular}{|c|c|c|c|c|c|c|}
\hline & \multicolumn{3}{|c|}{ Old cohort } & \multicolumn{3}{|c|}{ Young cohort } \\
\hline & $\mathrm{N}$ & Mean & Std. Dev. & $\mathrm{N}$ & Mean & Std. Dev. \\
\hline Years of schooling & 1,858 & 6.62 & 6.48 & 2,633 & 9.78 & 5.72 \\
\hline No degree & 1,858 & 0.44 & 0.50 & 2,633 & 0.20 & 0.40 \\
\hline Primary/preparatory degree & 1,858 & 0.17 & 0.37 & 2,633 & 0.17 & 0.37 \\
\hline Secondary degree & 1,858 & 0.19 & 0.39 & 2,633 & 0.35 & 0.48 \\
\hline Post-secondary degree & 1,858 & 0.20 & 0.40 & 2,633 & 0.28 & 0.45 \\
\hline Father: years of schooling & 1,860 & 1.67 & 4.05 & 2,648 & 2.70 & 5.07 \\
\hline Father: No degree & 1,860 & 0.84 & 0.37 & 2,648 & 0.75 & 0.43 \\
\hline Father: Primary/preparatory degree & 1,860 & 0.09 & 0.28 & 2,648 & 0.11 & 0.32 \\
\hline Father: Secondary degree & 1,860 & 0.04 & 0.20 & 2,648 & 0.07 & 0.26 \\
\hline Father: Post-secondary degree & 1,860 & 0.04 & 0.19 & 2,648 & 0.07 & 0.25 \\
\hline Farmers & 1,624 & 0.26 & 0.44 & 2,320 & 0.17 & 0.38 \\
\hline Semi/Unskilled manual & 1,624 & 0.13 & 0.34 & 2,320 & 0.16 & 0.36 \\
\hline Skilled manual & 1,624 & 0.17 & 0.38 & 2,320 & 0.24 & 0.42 \\
\hline White collar & 1,624 & 0.17 & 0.37 & 2,320 & 0.16 & 0.37 \\
\hline Professional & 1,624 & 0.27 & 0.44 & 2,320 & 0.28 & 0.45 \\
\hline Wage workers: formal job & 1,166 & 0.60 & 0.49 & 1,748 & 0.45 & 0.50 \\
\hline Wage workers: government sector job & 1,166 & 0.57 & 0.50 & 1,748 & 0.34 & 0.47 \\
\hline Father: farmers & 1,850 & 0.47 & 0.50 & 2,571 & 0.35 & 0.48 \\
\hline Father: semi/unskilled manual & 1,850 & 0.12 & 0.32 & 2,571 & 0.15 & 0.36 \\
\hline Father: skilled manual & 1,850 & 0.11 & 0.31 & 2,571 & 0.13 & 0.34 \\
\hline Father: white collar & 1,850 & 0.12 & 0.32 & 2,571 & 0.16 & 0.37 \\
\hline Father: professional & 1,850 & 0.19 & 0.39 & 2,571 & 0.21 & 0.41 \\
\hline Urban residence & 1,860 & 0.47 & 0.50 & 2,650 & 0.46 & 0.50 \\
\hline Urban residence at birth & 1,860 & 0.44 & 0.50 & 2,650 & 0.45 & 0.50 \\
\hline
\end{tabular}

Notes: "Years of schooling" is based on the highest educational degree obtained. Employment-related information refers to the occupation at age 28. A "formal" job is defined as a job with a wage contract and social insurance. Based on the ELMPS06 (weighted).

otherwise stated, descriptive statistics are based on the weighted data. ${ }^{13}$

Summary statistics for both cohorts are presented in Table 1. The old cohort, i.e. men born in 1949-1960, comprises 1,860 individuals, while the young cohort, i.e. men born in 1968-1977, comprises 2,650 individuals. This strong increase in the sample size reflects the overall high population growth in Egypt. When the father is absent from the household, the interviewee was asked about his father's education, i.e. the highest degree obtained, as well as the father's occupation when the interviewee was 15 . For sons living together with their fathers, this information is derived from the household

\footnotetext{
${ }^{13}$ Since data collection took place in December 2005 and early 2006, information such as an individual's age generally refers to the year 2005 .
} 


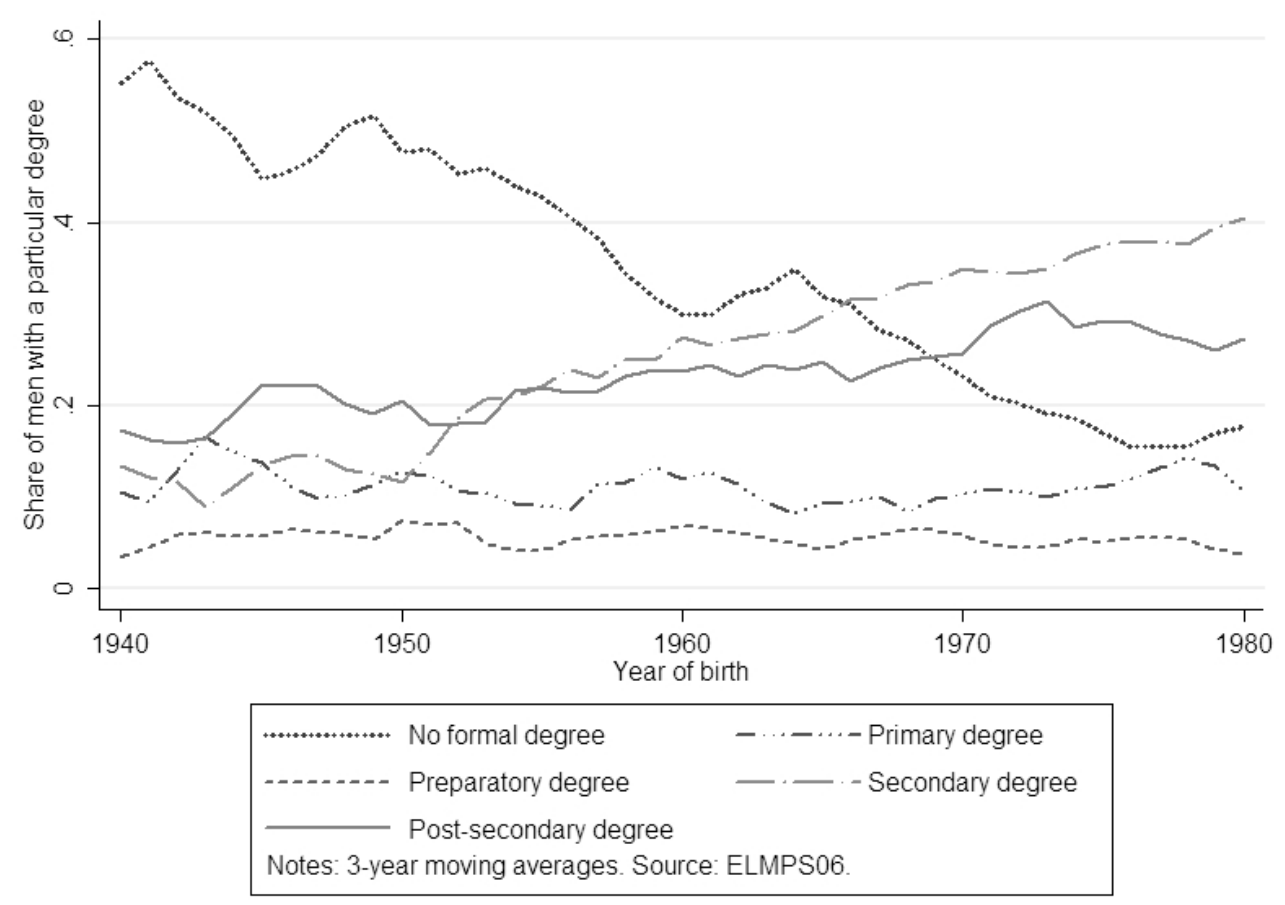

Notes: 3-year moving averages. Source: ELMPS06.

Figure 1: Changes in Educational Attainment of Men over Time, by Year of Birth.

questionnaire.

For both fathers and their sons, educational degrees are grouped into the following major categories: no (formal) degree, lower-secondary degree (i.e. primary and preparatory degree), secondary school degree and post-secondary degree, a category which also includes 5-year technical secondary-school graduates. Alternatively, education is measured in terms of years of schooling based on the final degree obtained, i.e. 0 years for no formal education, 6 years for primary education, 9 years for preparatory education, 12 years for secondary education, 14 years for five-year technical secondary education, 16 years for university education and 19 for graduate education.

Figure 1 clearly shows the strong decline over the past decades in the share of men with no formal educational degree. At the same time, both the share of men with a secondary school degree or above has increased. The share of men with a primary or preparatory degree is comparatively small and has remained roughly unchanged. Figure 1 also illustrates the effect of the policy shift from university to technical secondary 
education in the 1980s that was described in section 2 .

The ELMPS06 contains information about an individual's first job, current job and - as part of the employment history section - up to two previous jobs. Employmentrelated information includes, among others, an individual's occupation, his waged status and, for wage workers, whether he has a work contract and/or social insurance as well as his sector of employment. ${ }^{14}$ A job is defined as formal if it provides both a work contract and social insurance. Intensive data cleaning and consistency checks of the employment history section revealed that merely $4.13 \%$ of men aged $20-65(\mathrm{~N}=8,977)$ had had more than three jobs at the time of the survey. ${ }^{15}$ For $2.48 \%$ of men in this age group, the employment history section contains inconsistencies or errors, or it lacks information about the year an individual started an activity and/or about his employment status. In total, valid information is available for $93.39 \%$ of men aged 20 to 65 .

Similar to categories used elsewhere by economists (e.g., Schmidt and Strauss, 1975; Long and Ferrie, 2007), the following five occupational categories were constructed: professionals (i.e. lower and higher service workers), (other) white-collar workers (i.e. routine non-manual), skilled manual laborers, semi/unskilled manual laborers and farmers. For details about the construction of the occupational categories and their relation to various job characteristics, including earnings, see Appendix A. These descriptive statistics show, among other things, that professional and - to a lesser extent - white collar occupations are highly correlated with job formality and (for older cohorts) working in the government sector. In view of the decline in real wages, formal jobs in the government sector may not necessarily be associated with earning a high wage. Nevertheless, formal, non-manual jobs even if located in the public sector have been preferred as primary jobs over manual, mostly informal jobs as they provide households with a stable stream of income and access to a wide range of goods and services (Assaad, 1997). Also note that as a result of the decline in government sector jobs the composition of the workforce has changed over the considered time period. Among men with secondary and post-secondary degrees, for example, the share of men in wage employment at the age of 28 has declined from $92 \%$ for men of the old cohort (born in 1949-1960) to $78 \%$ for men of the young cohort (born in 1968-1977).

To deal with the potential life-cycle bias in intergenerational mobility estimates (see e.g., Erikson, Goldthorpe and Portocarero, 1983; Nicoletti and Ermisch, 2007), sons'

\footnotetext{
${ }^{14}$ Note that the terms government sector and public sector are used interchangeably.

${ }^{15}$ For a small number of men, whose earliest job in the employment history section started at most one year after they took up their first job, it is assumed that they did not experience any job change between their first job and the earliest job in the employment history section. These men are therefore included in the analysis.
} 
Table 2: Job versus Occupational Changes for Men Aged 20-65.

\begin{tabular}{lcccccccccccc}
\hline \hline & \multicolumn{4}{c}{ Age at obtaining first, etc. job } & \multicolumn{4}{c}{ Age at obtaining first, etc. occupation } \\
& Mean & Std. Dev. & N & Min & Max & & Mean & Std. Dev. & N & Min & Max \\
\hline 1st & 17.57 & 5.36 & 8,373 & 6 & 41 & 1st & 17.57 & 5.36 & 8,373 & 6 & 41 \\
2nd & 23.98 & 9.08 & 5,850 & 6 & 63 & 2nd & 27.59 & 8.16 & 2,526 & 7 & 61 \\
3rd & 29.69 & 9.80 & 1,908 & 10 & 63 & 3rd & 34.62 & 10.74 & 301 & 16 & 61 \\
4th & 33.62 & 10.34 & 261 & 14 & 60 & 4th & 33.50 & 8.07 & 6 & 25 & 48 \\
\hline
\end{tabular}

occupational characteristics are compared at a particular age. The selection of a reference age has trade-offs. While most men should have reached their permanent occupational status, i.e. "occupational maturity" (Erikson, Goldthorpe and Portocarero, 1983), by the reference age, we would also like to avoid dropping young individuals from the sample. Table 2 provides descriptive statistics concerning the age at which men started their first, second, etc. job and occupation. Hence, the right-hand side of the table takes only job changes into consideration that implied an occupational change as well. In general, men in Egypt start working at an early age. This is particularly true of men in the old cohort, in which $38 \%$ of males started working by the age 15. Furthermore, relatively few changed jobs several times and if they did, it was usually at the beginning of their careers. If we consider only job changes that result in an occupational change, a high share of men had a maximum of two changes. On average, men were 28 when they experienced this second occupational change. For this reason, the age of 28 is chosen as reference age. At this age, $99 \%$ of men aged 20-65 (with a valid job path) had obtained their first job. The main assumption being made is that men's transition to their permanent occupational status has not changed across the two cohorts, or rather that this transition is on average completed by the time they turn 28 . Given that by the age of 28 , even university graduates have been exposed to the labor market for several years, changes in the transition from school to work should have little effect. Nonetheless, as part of the sensitivity analysis, sons' occupations are compared at age 30 (see section 6.3).

Out of all men aged 28 to 65 , there was consistent data in $92 \%$ of cases. As part of the robustness analysis, men's current and first job in the event of missing data is used (see section 6.3 ). $12 \%$ of the male sample (aged 28-65) had experienced one unemployment phase by the time of the survey and less than $1 \%$ had experienced two phases. ${ }^{16}$ Most of these men were unemployed early in life after leaving school and before obtaining

\footnotetext{
${ }^{16}$ Similarly, "jobless" periods including temporarily disability and the residual category "other" have essentially occurred prior to age 28 .
} 
their first job. This reflects the fact that in Egypt unemployment is essentially a schoolto-work-transition problem (World Bank, 2004b; Assaad, 2009). Also, there are no (or little) social welfare benefits that can be claimed. Less than $10 \%$ of those who had experienced unemployment had been affected at age 28 or later and only a couple of individuals at age 28. Consequently, not working does not constitute a category of its own. Instead, the occupation prior to the unemployment period is used for those who were unemployed at age 28 .

Out of all sons with valid employment history information, the father's occupational status when the son was aged 15 and father's years of schooling were available in $98 \%$ of cases. Missing information was most often related to the fathers' occupation, i.e. to fathers who were living in the household at the time of the survey and who had missing entries in the employment history section. Less than $1 \%$ of fathers were recalled by interviewees as not working when the interviewee was 15 . These fathers and sons were dropped from the empirical analysis. As there is no information about fathers' year of birth for those not living together with their son, it is not possible to control for life-cycle effects for fathers. However, as fathers are typically well in their 30s or older when the son was aged 15 , life-cycle effects should matter little.

From the migration history section, one can infer an individual's place of residence at birth, i.e. whether he was born in a rural or in an urban area. Residence at birth instead of sons' current residence is used due to the fact that migration is likely to be endogenous. Using instead the sons' place of residence at the time of the survey affects mainly the old cohort, as rural-urban migration was stronger then (see section 6.3).

\section{$6 \quad$ Results}

Before examining whether there has been a decline in intergenerational economic mobility across cohorts of graduates, this section provides evidence for a strong increase in intergenerational educational mobility, including increased secondary schooling and above for those from a low socio-economic background. Thus, the first subsection provides suggestive evidence that the expansion of the educational system, together with the employment guarantee scheme, created aspirations among low-income families to move up socially. 
Table 3: Overall Change in Intergenerational Educational Mobility.

\begin{tabular}{lcc}
\hline \hline & $1949-1960$ Cohort & 1968-1977 Cohort \\
\hline Upwardly mobile & 0.50 & 0.68 \\
Downwardly mobile & 0.02 & 0.02 \\
Immobile & 0.48 & 0.30 \\
\hline
\end{tabular}

Notes: Calculations are based on weighted mobility tables, see Table 14 in the Appendix.

Table 4: Outflow Percentages for Fathers' and Sons' Educational Attainment.

1949-1960 Cohort $(\mathrm{N}=1,858)$

\begin{tabular}{llrrrrr}
\hline \hline & & \multicolumn{5}{c}{ Son's education } \\
& & \multicolumn{1}{c}{$(1)$} & \multicolumn{1}{c}{$(2)$} & \multicolumn{1}{c}{$(3)$} & \multicolumn{1}{c}{$(4)$} & Total \\
\hline \multirow{3}{*}{ Father's } & (1) No degree & 51.24 & 18.32 & 18.12 & 12.32 & 100.00 \\
education & (2) Primary/preparatory degree & 12.74 & 13.57 & 26.58 & 47.11 & 100.00 \\
& (3) Secondary degree & 4.72 & 6.58 & 29.14 & 59.56 & 100.00 \\
& (4) Post-secondary degree & 0.00 & 1.54 & 12.22 & 86.24 & 100.00 \\
\hline \multirow{2}{*}{ Total } & 44.07 & 16.79 & 19.09 & 20.05 & 100.00
\end{tabular}

1968-1977 Cohort $(\mathrm{N}=2,631)$

\begin{tabular}{llrrrrc}
\hline \hline & & \multicolumn{5}{c}{ Son's education } \\
& & \multicolumn{1}{c}{$(1)$} & \multicolumn{1}{c}{$(2)$} & \multicolumn{1}{c}{$(3)$} & \multicolumn{1}{c}{$(4)$} & Total \\
\hline \multirow{3}{*}{ Father's } & (1) No degree & 25.87 & 19.54 & 36.11 & 18.48 & 100.00 \\
education & (2) Primary/preparatory degree & 6.07 & 13.55 & 41.13 & 39.26 & 100.00 \\
& (3) Secondary degree & 0.93 & 4.68 & 38.59 & 55.80 & 100.00 \\
& (4) Post-secondary degree & 0.47 & 1.52 & 10.03 & 87.97 & 100.00 \\
\hline \multirow{2}{*}{ Total } & 20.20 & 16.62 & 35.09 & 28.10 & 100.00
\end{tabular}

Source: ELMPS06.

\subsection{Intergenerational Educational Mobility across Cohorts}

Table 3 displays overall shares of downward, upward and immobile sons belonging to the old and the young cohort. ${ }^{17}$ These statistics suggest that intergenerational educational mobility has indeed increased markedly from the old to the young cohort: the share of upwardly mobile men went up from $50 \%$ to $68 \%$. This increase is entirely due to a

\footnotetext{
${ }^{17}$ These shares are calculated based on the mobility table of each cohort, see Table 14 in the Appendix. Below the diagonal in the mobility table are sons who earned a higher degree than their fathers, i.e. are upwardly mobile, while sons above the diagonal are less educated than their fathers, i.e. are downwardly mobile.
} 
decrease in the share of immobile men.

To get a better idea of which father-son pairs drive overall upward mobility, Table 4 shows the outflow percentages for the father-son pairs of both cohorts. Outflow percentages provide information about the distribution of the son's educational attainment while keeping father's education fixed. They indicate that upward movements not only occurred into the next category but also that the sons of fathers with no educational attainment achieved secondary education or above: among the young cohort, $36 \%$ of men whose father had no formal degree achieved a secondary school degree and $18 \%$ achieved a post-secondary degree. The outflow percentages also suggest a strong decline in immobility at the bottom of the educational distribution. In the old cohort, $51 \%$ of men whose fathers did not earn any formal degree also ended up having no formal degree, whereas this share decreased to $26 \%$ for the young cohort. Overall, therefore, there has been an impressive increase in educational mobility between generations.

Analog to equation (6), the upper part of Table 5 presents ordinary least squares (OLS) results for regressing a son's years of education on his father's years of education, a dummy for belonging to the young cohort, an interaction term between these two terms and year of birth dummies. ${ }^{18}$ For men of the old cohort, one additional year of schooling for the father is associated with an increase in 0.7 years of schooling for the son. This association decreases significantly by 0.3 years for men of the young cohort. In light of the fact that schooling used to be less available in rural areas than in urban ones, one would expect a stronger association between father's and son's years of schooling in rural areas. This is indeed the case, as shown in the fourth and fifth columns. The results, however, also suggest that rural areas have been catching up with urban areas in providing more equal educational opportunities.

In an alternative specification, father's schooling is measured as a categorical variable (no educational degree, primary/preparatory degree, secondary degree, and postsecondary degree). This allows one to examine whether the relationship between fathers' and sons' education is non-linear and to grasp what is driving changes in the mean association between fathers' and sons' education. Results for this alternative specification are presented in the lower part of Table 5 . There is a particularly strong negative association between fathers without any formal degree and sons' years of schooling: in comparison

\footnotetext{
${ }^{18}$ For clarity of exposition only the coefficients of the main variables of interest are reported. Alternatively, son's education is regressed on parents' education, i.e. the average of the father's and mother's education. Coefficient estimates are very similar but slightly larger than those estimated by Hertz et al. (2007) based on survey data collected by IFPRI in 1997. Note that there is little variation in mother's education as few mothers earned a formal degree; $95 \%$ of mothers from the old cohort and $87 \%$ of mothers from the young cohort have no formal degree.
} 
Table 5: Relationship between Father's Education and Son's Years of Schooling.

\begin{tabular}{|c|c|c|c|c|c|}
\hline & \multicolumn{5}{|c|}{ Dependent variable: son's years of schooling } \\
\hline & Old cohort & Young cohort & Full sample & Rural & Urban \\
\hline Fa: years of schooling & $\begin{array}{l}0.698^{* * *} \\
(0.027)\end{array}$ & $\begin{array}{l}0.440^{* * *} \\
(0.015)\end{array}$ & $\begin{array}{l}0.698^{* * *} \\
(0.027)\end{array}$ & $\begin{array}{l}0.871^{* * *} \\
(0.073)\end{array}$ & $\begin{array}{l}0.530^{* * *} \\
(0.030)\end{array}$ \\
\hline $\begin{array}{l}\text { Fa: years of schooling } \\
\quad \times \text { young cohort }(\mathrm{d})\end{array}$ & & & $\begin{array}{l}-0.258^{* * *} \\
(0.031)\end{array}$ & $\begin{array}{l}-0.393^{* * *} \\
(0.079)\end{array}$ & $\begin{array}{l}-0.172^{* * *} \\
(0.035)\end{array}$ \\
\hline $\begin{array}{l}\mathrm{N} \\
R^{2}\end{array}$ & $\begin{array}{c}1,878 \\
0.2109\end{array}$ & $\begin{array}{c}2,671 \\
0.1576\end{array}$ & $\begin{array}{c}4,549 \\
0.2337\end{array}$ & $\begin{array}{c}2,106 \\
0.2018\end{array}$ & $\begin{array}{c}2,443 \\
0.2294\end{array}$ \\
\hline Alternative specification: & & & & & \\
\hline Fa: no degree & $\begin{array}{l}-7.879 * * * \\
(0.493)\end{array}$ & $\begin{array}{l}-5.224^{* * *} \\
(0.268)\end{array}$ & $\begin{array}{l}-7.879 * * * \\
(0.492)\end{array}$ & $\begin{array}{c}-10.220^{* * *} \\
(1.025)\end{array}$ & $\begin{array}{l}-5.841^{* * *} \\
(0.554)\end{array}$ \\
\hline Fa: primary/preparatory degree & $\begin{array}{c}-1.684^{* *} \\
(0.690)\end{array}$ & $\begin{array}{l}-1.836^{* * *} \\
(0.342)\end{array}$ & $\begin{array}{l}-1.684^{* *} \\
(0.689)\end{array}$ & $\begin{array}{l}-3.335^{* *} \\
(1.368)\end{array}$ & $\begin{array}{r}-1.252 \\
(0.766)\end{array}$ \\
\hline Fa: post-secondary degree & $\begin{array}{l}2.249^{* * *} \\
(0.566)\end{array}$ & $\begin{array}{l}1.591^{* * *} \\
(0.276)\end{array}$ & $\begin{array}{l}2.249^{* * * *} \\
(0.566)\end{array}$ & $\begin{array}{l}0.708 \\
(1.707)\end{array}$ & $\begin{array}{l}2.439^{* * *} \\
(0.595)\end{array}$ \\
\hline $\begin{array}{l}\text { Fa: no degree } \\
\quad \times \text { young cohort }(\mathrm{d})\end{array}$ & & & $\begin{array}{l}2.654^{* * *} \\
(0.560)\end{array}$ & $\begin{array}{l}4.253^{* * *} \\
(1.177)\end{array}$ & $\begin{array}{l}1.829^{* * *} \\
(0.632)\end{array}$ \\
\hline $\begin{array}{c}\text { Fa: primary/preparatory degree } \\
\times \text { young cohort }(\mathrm{d})\end{array}$ & & & $\begin{array}{r}-0.152 \\
(0.770)\end{array}$ & $\begin{array}{c}0.780 \\
(1.568)\end{array}$ & $\begin{array}{r}-0.212 \\
(0.847)\end{array}$ \\
\hline $\begin{array}{l}\text { Fa: post-secondary degree } \\
\quad \times \text { young cohort }(\mathrm{d})\end{array}$ & & & $\begin{array}{c}-0.659 \\
(0.630)\end{array}$ & $\begin{array}{c}0.271 \\
(1.836)\end{array}$ & $\begin{array}{c}-0.618 \\
(0.663)\end{array}$ \\
\hline $\mathrm{N}$ & 1,878 & 2,671 & 4,549 & 2,106 & 2,443 \\
\hline$R^{2}$ & 0.2162 & 0.1560 & 0.2353 & 0.2007 & 0.2318 \\
\hline
\end{tabular}

${ }^{*} \mathrm{p}<0.10,{ }^{* *} \mathrm{p}<0.05, * * * \mathrm{p}<0.01$

Notes: OLS results are reported with standard errors controlling for clustering at the household level in parentheses. All specifications include dummies for the son's year of birth and a constant. "Old" cohort refers to men born 1949-1960 while "young" cohort refers to men born 1968-1977. "Urban areas" and "rural areas" refer to the place of residence at birth. The reference category for father's education in the alternative specification is "secondary degree".

to fathers with a secondary school education, sons of fathers without a formal degree have nearly 8 less years of schooling. Particularly in rural areas, sons of fathers with no formal degree or - although to a lesser extent - with a primary or preparatory degree were disadvantaged. Yet there was also no extra benefit in rural areas from having a father with a post-secondary degree as compared to a secondary school degree. In urban areas, by contrast, the sons of fathers with a university degree do experience a benefit, which has not declined significantly over time. This may be a first sign of lower mobility at the top of the educational distribution.

Table 6 reports the OLS results from estimating the son's likelihood of obtaining a secondary school degree or higher (i) and a post-secondary degree (ii). ${ }^{19}$ As before,

\footnotetext{
${ }^{19}$ Probit estimates were similar to ordinary least squares (OLS) estimates, except for the specification
} 
Table 6: Relationship between Father's Education and the Son Obtaining a Secondary Degree (and above).

\begin{tabular}{|c|c|c|c|c|c|c|}
\hline & \multicolumn{6}{|c|}{ Dependent variable: son with } \\
\hline & \multicolumn{3}{|c|}{ (i) a secondary degree or above } & \multicolumn{3}{|c|}{ (ii) a post-secondary degree } \\
\hline & Full sample & Rural & Urban & Full sample & Rural & Urban \\
\hline Fa: years of schooling & $\begin{array}{l}0.049^{* * *} \\
(0.002)\end{array}$ & $\begin{array}{l}0.059^{* * *} \\
(0.005)\end{array}$ & $\begin{array}{l}0.038^{* * *} \\
(0.002)\end{array}$ & $\begin{array}{l}0.045^{* * *} \\
(0.003)\end{array}$ & $\begin{array}{l}0.045^{* * *} \\
(0.007)\end{array}$ & $\begin{array}{l}0.041^{* * *} \\
(0.003)\end{array}$ \\
\hline $\begin{array}{l}\text { Fa: years of schooling } \\
\quad \times \text { young cohort }(\mathrm{d})\end{array}$ & $\begin{array}{l}-0.018^{* * *} \\
(0.002)\end{array}$ & $\begin{array}{l}-0.026^{* * *} \\
(0.006)\end{array}$ & $\begin{array}{l}-0.012^{* * *} \\
(0.003)\end{array}$ & $\begin{array}{c}-0.007^{* *} \\
(0.003)\end{array}$ & $\begin{array}{r}-0.007 \\
(0.008)\end{array}$ & $\begin{array}{r}-0.006^{*} \\
(0.004)\end{array}$ \\
\hline $\begin{array}{l}\mathrm{N} \\
R^{2}\end{array}$ & $\begin{array}{c}4,549 \\
0.1875\end{array}$ & $\begin{array}{c}2,106 \\
0.1676\end{array}$ & $\begin{array}{c}2,443 \\
0.1800\end{array}$ & $\begin{array}{c}4,549 \\
0.2026\end{array}$ & $\begin{array}{c}2,106 \\
0.1373\end{array}$ & $\begin{array}{c}2,443 \\
0.2104\end{array}$ \\
\hline \multicolumn{7}{|l|}{ Alternative specification: } \\
\hline Fa: no degree & $\begin{array}{l}-0.628^{* * *} \\
(0.026)\end{array}$ & $\begin{array}{l}-0.765^{* * *} \\
(0.038)\end{array}$ & $\begin{array}{l}-0.503^{* * *} \\
(0.032)\end{array}$ & $\begin{array}{l}-0.594^{* * *} \\
(0.041)\end{array}$ & $\begin{array}{l}-0.520^{* * *} \\
(0.125)\end{array}$ & $\begin{array}{l}-0.560^{* * *} \\
(0.043)\end{array}$ \\
\hline Fa: primary/preparatory degree & $\begin{array}{l}-0.204^{* * *} \\
(0.047)\end{array}$ & $\begin{array}{c}-0.339^{* * *} \\
(0.087)\end{array}$ & $\begin{array}{c}-0.159^{* * *} \\
(0.051)\end{array}$ & $\begin{array}{l}-0.251^{* * *} \\
(0.059)\end{array}$ & $\begin{array}{r}-0.145 \\
(0.149)\end{array}$ & $\begin{array}{c}-0.264^{* * *} \\
(0.065)\end{array}$ \\
\hline $\begin{array}{l}\text { Fa: no degree } \\
\quad \times \text { young cohort }(\mathrm{d})\end{array}$ & $\begin{array}{l}0.217^{* * *} \\
(0.031)\end{array}$ & $\begin{array}{l}0.349^{* * *} \\
(0.054)\end{array}$ & $\begin{array}{l}0.137^{* * *} \\
(0.039)\end{array}$ & $\begin{array}{c}0.062 \\
(0.049)\end{array}$ & $\begin{array}{r}-0.007 \\
(0.139)\end{array}$ & $\begin{array}{c}0.068 \\
(0.054)\end{array}$ \\
\hline $\begin{array}{c}\text { Fa: primary/preparatory degree } \\
\times \text { young cohort }(\mathrm{d})\end{array}$ & $\begin{array}{c}0.045 \\
(0.054)\end{array}$ & $\begin{array}{c}0.176^{*} \\
(0.107)\end{array}$ & $\begin{array}{c}0.004 \\
(0.058)\end{array}$ & $\begin{array}{r}-0.075 \\
(0.071)\end{array}$ & $\begin{array}{r}-0.170 \\
(0.170)\end{array}$ & $\begin{array}{r}-0.057 \\
(0.080)\end{array}$ \\
\hline $\mathrm{N}$ & 4,549 & 2,106 & 2,443 & 4,549 & 2,106 & 2,443 \\
\hline$R^{2}$ & 0.1884 & 0.1661 & 0.1810 & 0.1935 & 0.1335 & 0.1981 \\
\hline
\end{tabular}

$* \mathrm{p}<0.10, * * \mathrm{p}<0.05, * * * \mathrm{p}<0.01$

Notes: OLS results are reported with standard errors controlling for clustering at the household level in parentheses. All specifications include dummies for the son's year of birth and a constant. "Full sample" includes both the "old" cohort (i.e. men born 1949-1960) and the "young" cohort (i.e. men born 1968-1977). "Urban areas" and "rural areas" refer to the place of residence at birth. The reference category for father's education in the alternative specification is "secondary degree and above".

the upper part of the table shows results for measuring father's education in terms of years of schooling while the lower part of the table displays results for specifying father's education as a categorical variable. Because of the small share of fathers with a postsecondary degree, the reference category now comprises fathers with both a secondary school degree and a post-secondary degree. ${ }^{20}$ The estimates for the son's probability of obtaining a secondary school degree or above are in line with earlier results - namely, the decline in the association between fathers' and sons' education is driven not only by the fact that many men of the young cohort obtain just a few years of schooling, but also by

in (i), urban areas. Here, the probit estimates for the interaction terms with the father's educational attainment are not statistically significant.

${ }^{20}$ Using OLS would have allowed the renewed use of the earlier reference category. However, it would then not be possible to compare results to probit estimates. 
the increased access to secondary and post-secondary education. Furthermore, similar to the results for sons' years of schooling, among the old cohort, a father's education has been more strongly correlated with the son's education in rural areas, but this association has also declined more strongly. Specifically, in rural areas the association between an additional year of schooling for the father and the probability that the son will achieve at least a secondary school degree has dropped by almost half for men of the young cohort in comparison to the old cohort.

What about access to university education? Estimation results in the right part of Table 6 suggest that post-secondary education has, contrary to the results in the first three columns, remained somewhat exclusive both in rural and in urban areas. While in urban areas the estimates for the main specification indicate a significant decline in the relationship between fathers' years of schooling and sons' likelihood of achieving higher education, this decline is very small. There is also no significant change over time in the alternative specification. ${ }^{21}$

In terms of the theoretical framework, there are two possible explanations for an increase in educational attainment: a decrease in schooling costs - for instance, since new schools have been built - and an increase in the net expected gain of investing in schooling. The expansion of the educational system certainly played its role by reducing costs, but so did the employment guarantee scheme, by raising aspirations for moving up socially: as will be shown in the next section, nearly all (post-) secondary graduates of the old cohort, i.e. across the social strata, obtained a professional (formal) occupation. The different results for secondary and university education suggest that the costs to university education relative to secondary school education have remained high.

\subsection{Intergenerational Occupational Mobility across Cohorts}

Let us first take a look at the outflow percentages for both cohorts in Table $7 .^{22}$ Along the diagonal we observe little change for the non-manual and skilled manual occupations. Immobility seems to have decreased only among farmers (from 51\% to 40\%) and increased among the semi/unskilled manual laborers (from $22 \%$ to $29 \%$ ). Immobility has been and still is highest among professionals, at $56 \%$ for men of the young cohort. Despite substantial immobility, roughly one-quarter of sons with a father in a white-

\footnotetext{
${ }^{21}$ This is in line with preliminary results from the Survey of Young People in Egypt (SYPE), which reveals that only a small share of university students comes from the lower wealth quintiles (Population Council, 2010).

${ }^{22}$ The corresponding mobility tables are presented in the Appendix in Table 15. They show in particular the strong decline in the share of farmers over the past century. As no ranking is assumed, overall upward and downward mobilities have not been calculated.
} 
Table 7: Outflow Percentages for Fathers' and Sons' Occupational Attainment.

1949-1960 Cohort $(\mathrm{N}=1,617)$

\begin{tabular}{llrrrrrr}
\hline \hline & & \multicolumn{5}{c}{ Son's occupation } \\
& & \multicolumn{1}{c}{$(1)$} & \multicolumn{1}{c}{$(2)$} & \multicolumn{1}{c}{$(3)$} & \multicolumn{1}{c}{$(4)$} & \multicolumn{1}{c}{$(5)$} & Total \\
\hline \multirow{3}{*}{ Father's } & (1) Farmers & 51.48 & 10.94 & 9.30 & 12.16 & 16.13 & 100.00 \\
occupation & (2) Semi/unskilled manual & 5.27 & 22.03 & 21.76 & 21.14 & 29.80 & 100.00 \\
& (3) Skilled manual & 4.48 & 17.86 & 41.75 & 12.15 & 23.76 & 100.00 \\
& (4) White collar & 4.12 & 14.74 & 28.12 & 25.01 & 28.02 & 100.00 \\
& (5) Professional & 2.17 & 7.95 & 12.89 & 23.09 & 53.90 & 100.00 \\
\hline & Total & 26.35 & 12.95 & 17.28 & 16.71 & 26.70 & 100.00
\end{tabular}

1968-1977 Cohort $(\mathrm{N}=2,320)$

\begin{tabular}{llrrrrrr}
\hline \hline & & \multicolumn{5}{c}{ Son's occupation } \\
& & \multicolumn{1}{c}{$(1)$} & \multicolumn{1}{c}{$(2)$} & $(3)$ & $(4)$ & $(5)$ & Total \\
\hline \multirow{3}{*}{ Father's } & (1) Farmers & 40.26 & 12.75 & 21.97 & 10.25 & 14.78 & 100.00 \\
occupation & (2) Semi/unskilled manual & 6.46 & 29.35 & 21.08 & 16.94 & 26.17 & 100.00 \\
& (3) Skilled manual & 2.86 & 17.54 & 42.98 & 16.37 & 20.25 & 100.00 \\
& (4) White collar & 7.52 & 15.88 & 24.11 & 25.35 & 27.15 & 100.00 \\
& (5) Professional & 3.04 & 8.70 & 14.84 & 17.85 & 55.58 & 100.00 \\
\hline & Total & 17.43 & 15.49 & 23.46 & 16.00 & 27.62 & 100.00
\end{tabular}

Notes: Son's occupation refers to his occupation at age 28. Source: ELMPS06.

collar or manual profession had obtained a professional occupation by their late 20 s, the proportion being slightly lower for men born in 1968-1977. There is some permeability across all occupations except for farmers: relatively few men from outside seem to enter this occupation.

The marginal distributions indicate that the share of non-manual relative to manual occupations has not changed over time; the decrease in the share of farmers has essentially been associated with an increase in the share of other manual occupations. In light of the fact that the share of men with a secondary school degree or higher has increased markedly over the same period (from $39 \%$ to $63 \%$ ), this is surprising. It suggests that professional, and, more generally, non-manual occupations have become relatively scarce, which is confirmed in Figure 2. Among men with secondary school degrees and above, $83 \%$ (59\%) of the old cohort obtained a non-manual (professional) occupation by the age of 28 compared to $61 \%$ (41\%) of the young cohort. Among men with a university education, the decline is less drastic. Similarly, the share of formal jobs out of all wage work decreased: among secondary graduates and higher, $57 \%$ of the young cohort compared to $86 \%$ of the old cohort had a formal job by the age of 


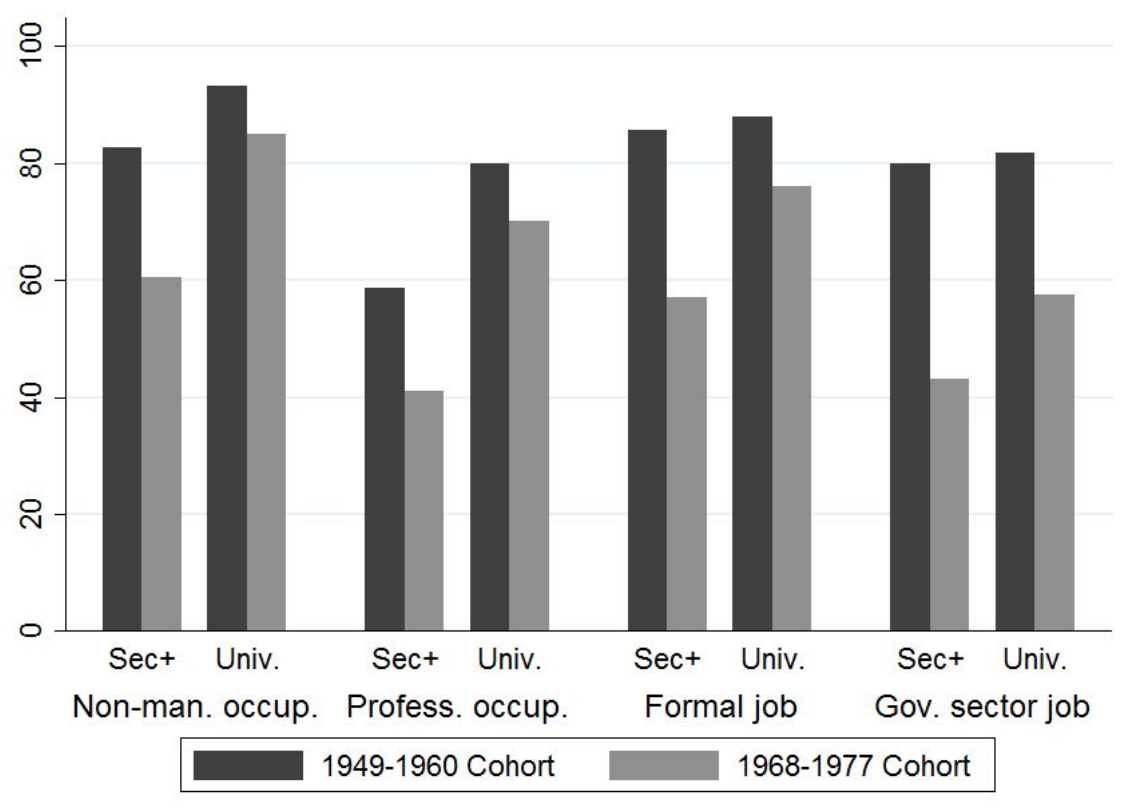

Figure 2: Changes in the Availability of Jobs across Cohorts.

Notes: This figure shows, separately for the old and the young cohort, the percentage of men with (i) secondary degrees and above and (ii) post-secondary (university) degrees, who had obtained a non-manual occupation (professional occupation / formal job / government sector job) by the age of 28. Source: ELMPS06.

28; among university graduates, the comparable figures are $76 \%$ and $88 \%$. Government sector employment has become more rare too: among university graduates, only $58 \%$ of the young cohort worked in the government sector compared to $82 \%$ of the old cohort; for secondary school graduates and higher the figures are $43 \%$ and $80 \%$, respectively. The decline in government sector employment has been more dramatic than the decline in formal jobs which shows that the private sector is increasingly offering non-manual, formal jobs too, especially for university graduates.

Based on the foregoing descriptive statistics, a significant share of secondary school graduates should hold a manual occupation. Figure 4 in the Appendix plots for each cohort the educational distribution of workers across occupations. While the tremendous increase in educational attainment over time has led to an overall increase in the average amount of schooling within each occupation, we can also see a strong increase in the share of men with a secondary degree who seem "stuck" in semi/unskilled manual work, such as taxi drivers and security guards. In fact, secondary school graduates make up by far the largest educational group of all semi/unskilled workers. Their share is also 
high among skilled manual employees. In contrast, relatively few university graduates hold a manual occupation.

Overall, the descriptive statistics demonstrate that the profound changes that have occurred in the labor market over the past decades did not "merely" affect the school-towork transition but had a more permanent effect on the labor market outcomes of many youth. Given the increasing scarcity of the preferred jobs, labor market competition among well-educated men in the young cohort has intensified. This increased competition all the more raises questions concerning who manages to actually obtain these jobs.

The upper part of Table 8 shows regression results for equation (6), i.e. relating the son's probability for attaining a professional occupation by the age of 28 - or, alternatively, a non-manual occupation (i.e. a white collar or a professional occupation), a formal job, or a government sector job - to whether or not his father worked as a professional. ${ }^{23}$ As hypothesized, for the old cohort, university graduates from the lower ranks of society were not disadvantaged. That is, once they achieved a university degree, they faced equal opportunities for attaining a professional occupation. However, this no longer holds true for university graduates of the young cohort: compared to university graduates of the old cohort, having a father working as a professional increases the son's likelihood of also becoming a professional by 19 percentage points, and it increases his likelihood of obtaining a formal job by 25 percentage points. In absolute terms, university graduates of the young cohort who come from a privileged background are 18 percentage points more likely to work as a professional compared to their counterparts, and 16 percentage points more likely to obtain a formal job.

For the old cohort, the "effect" of having a father working as a professional on the son's likelihood of obtaining a formal job is negative, albeit small. Note, however, that formal and government sector employment are both defined for wage workers only. The negative coefficient estimate thus likely reflects selection into non-wage employment, i.e. graduates from a higher socio-economic background used to be more likely to be self-employed or entrepreneurs than their less well-off counterparts.

Further, the results in column (4) indicate that the decline in mobility is associated with the way jobs are allocated in the formal private, rather than in the public sector. This is in line with the sociological literature cited earlier that has argued that graduates from a low socio-economic background lack the right skills and/or personal connections to obtain a professional position in the private sector. While the dataset does not allow one to discriminate between these two sources of inequality, the dataset does

\footnotetext{
${ }^{23}$ Estimating a probit instead of a linear probability model produces very similar results (see also section 6.3).
} 
Table 8: Among Sons with Post-Secondary (University) Degrees: Relationship between Father's Occupation and Son's Occupation/Job (at Age 28).

\begin{tabular}{|c|c|c|c|c|}
\hline & $\begin{array}{c}\text { Dep. } \\
(1) \\
\text { non-manual } \\
\text { occupation }\end{array}$ & $\begin{array}{c}\text { iriable: son's } 1 \\
(2) \\
\text { professional } \\
\text { occupation }\end{array}$ & $\begin{array}{l}\text { obability to } \\
\text { (3) } \\
\text { formal job }\end{array}$ & $\begin{array}{l}\text { tain a } \\
\qquad(4) \\
\text { gov. sector } \\
\text { job }\end{array}$ \\
\hline \multicolumn{5}{|l|}{ Specification A: } \\
\hline Fa: professional $(\mathrm{d})$ & $\begin{array}{c}0.029 \\
(0.027)\end{array}$ & $\begin{array}{c}-0.002 \\
(0.050)\end{array}$ & $\begin{array}{r}-0.087^{*} \\
(0.050)\end{array}$ & $\begin{array}{c}0.009 \\
(0.052)\end{array}$ \\
\hline $\begin{array}{l}\text { Fa: professional } \\
\quad \times \text { young cohort }(\mathrm{d})\end{array}$ & $\begin{array}{l}0.111^{* * *} \\
(0.038)\end{array}$ & $\begin{array}{l}0.187^{* * *} \\
(0.062)\end{array}$ & $\begin{array}{l}0.251^{* * *} \\
(0.060)\end{array}$ & $\begin{array}{c}0.003 \\
(0.070)\end{array}$ \\
\hline $\begin{array}{l}\mathrm{N} \\
R^{2}\end{array}$ & $\begin{array}{l}1,002 \\
0.061\end{array}$ & $\begin{array}{l}1,002 \\
0.085\end{array}$ & $\begin{array}{c}870 \\
0.099\end{array}$ & $\begin{array}{c}870 \\
0.125\end{array}$ \\
\hline $\begin{array}{l}\text { Specification B: } \\
\text { Fa: farmer }\end{array}$ & $\begin{array}{c}0.062 \\
(0.081)\end{array}$ & $\begin{array}{r}-0.042 \\
(0.091)\end{array}$ & $\begin{array}{c}0.053 \\
(0.081)\end{array}$ & $\begin{array}{c}0.063 \\
(0.110)\end{array}$ \\
\hline Fa: semi/unsk. manual & $\begin{array}{c}0.056 \\
(0.080)\end{array}$ & $\begin{array}{r}-0.056 \\
(0.094)\end{array}$ & $\begin{array}{c}0.074 \\
(0.074)\end{array}$ & $\begin{array}{c}0.094 \\
(0.113)\end{array}$ \\
\hline Fa: white collar & $\begin{array}{c}0.052 \\
(0.086)\end{array}$ & $\begin{array}{c}-0.142 \\
(0.101)\end{array}$ & $\begin{array}{r}-0.055 \\
(0.089)\end{array}$ & $\begin{array}{r}-0.010 \\
(0.120)\end{array}$ \\
\hline Fa: professional & $\begin{array}{c}0.082 \\
(0.070)\end{array}$ & $\begin{array}{c}-0.076 \\
(0.083)\end{array}$ & $\begin{array}{c}-0.072 \\
(0.073)\end{array}$ & $\begin{array}{c}0.048 \\
(0.109)\end{array}$ \\
\hline $\begin{array}{l}\text { Fa: farmer } \\
\quad \times \text { young cohort }(\mathrm{d})\end{array}$ & $\begin{array}{r}-0.014 \\
(0.109)\end{array}$ & $\begin{array}{c}0.223^{*} \\
(0.122)\end{array}$ & $\begin{array}{c}0.087 \\
(0.122)\end{array}$ & $\begin{array}{c}0.110 \\
(0.141)\end{array}$ \\
\hline $\begin{array}{l}\text { Fa: semi/unsk. manual } \\
\quad \times \text { young cohort }(\mathrm{d})\end{array}$ & $\begin{array}{c}0.055 \\
(0.110)\end{array}$ & $\begin{array}{c}0.170 \\
(0.132)\end{array}$ & $\begin{array}{c}0.090 \\
(0.120)\end{array}$ & $\begin{array}{c}0.140 \\
(0.147)\end{array}$ \\
\hline $\begin{array}{l}\text { Fa: white collar } \\
\quad \times \text { young cohort }(\mathrm{d})\end{array}$ & $\begin{array}{c}0.108 \\
(0.112)\end{array}$ & $\begin{array}{r}0.238^{*} \\
(0.133)\end{array}$ & $\begin{array}{c}0.111 \\
(0.131)\end{array}$ & $\begin{array}{c}0.158 \\
(0.152)\end{array}$ \\
\hline $\begin{array}{l}\text { Fa: professional } \\
\quad \times \text { young cohort }(\mathrm{d})\end{array}$ & $\begin{array}{c}0.148 \\
(0.094)\end{array}$ & $\begin{array}{l}0.368^{* * *} \\
(0.112)\end{array}$ & $\begin{array}{l}0.331^{* * *} \\
(0.111)\end{array}$ & $\begin{array}{c}0.115 \\
(0.136)\end{array}$ \\
\hline $\begin{array}{l}\mathrm{N} \\
R^{2}\end{array}$ & $\begin{array}{l}1,002 \\
0.074\end{array}$ & $\begin{array}{l}1,002 \\
0.094\end{array}$ & $\begin{array}{c}870 \\
0.111\end{array}$ & $\begin{array}{c}870 \\
0.135\end{array}$ \\
\hline \multicolumn{5}{|c|}{$\begin{array}{l}* \mathrm{p}<0.10,{ }^{*} \mathrm{p}<0.05,{ }^{* *} \mathrm{p}<0.01 \\
\text { Reference category (specification B): "skilled manual". } \\
\text { Notes: OLS coefficient estimates are reported with robust standard errors controlling for } \\
\text { clustering at the household level in parentheses. Non-manual occupations comprise white } \\
\text { collar and professional occupations. All specifications include a dummy for belonging to the } \\
\text { young cohort, dummies for the son's year of birth, a dummy for being born in an urban area, } \\
\text { and a constant. }\end{array}$} \\
\hline
\end{tabular}

provide information about the main and the secondary (if there was a secondary) job search method used to obtain the current primary job, including whether the current job was obtained with the help of relatives or friends. ${ }^{24}$ Figure 3 shows the percentage of

\footnotetext{
${ }^{24}$ Alternative methods were: registered in government employment or private employment office, entered government job lottery competition, sent job application, inquired at the work site, advertised in
} 


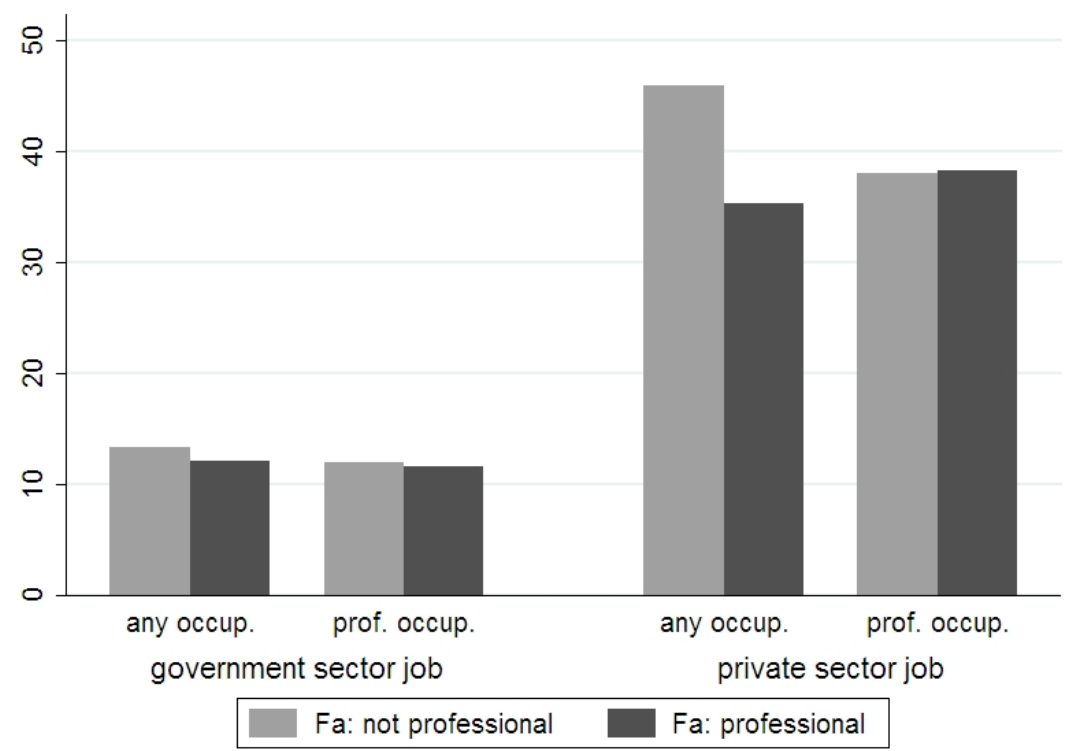

Figure 3: University Graduates of the Young Cohort who Found their Current Job through Relatives or Friends

Notes: This figure shows the percentage of post-secondary graduates who state as their main or secondary job search method for their current main job that they received help from relatives or friends, separate for (i) whether their current job is located in the public or the private sector, (ii) unconditional or conditional on currently holding a professional occupation, and (iii) whether or not their father is working as a professional. Source: ELMPS06.

university graduates of the young cohort who state that they received their current main job through relatives or friends. The percentages are presented depending on the sector of employment and the occupational status of the father. Note that since this information is not available for previous employment positions, comparing job search methods across cohorts is problematic. As regards government sector employment, figures are very similar, however, for the old cohort; as regards private sector employment, there are very few university graduates from the old cohort with their current primary job located in the private sector. While there is likely selection into the sector of employment, the share of university graduates that received help from their family or friends is markedly high (close to 40 percent) for those who work in the private sector and succeed in attaining a professional occupation. In contrast, the corresponding share for graduates who take a job in the public sector is only slightly over 10 percent. This suggests that

newspapers, applied to a job advertised in newspapers, contacted employer, contacted contractor, waited at gathering locations, searched for a private project, arranged to get financing for a private project, and other. 
the decline in social mobility may be related, at least in part, to not having the right personal connections to secure such an occupation.

The lower part of Table 8 demonstrates that these findings remain robust when using a more comprehensive occupational measure for fathers, with the exception of column (1). However, a white-collar occupation is not perceived as an "appropriate" job for a university graduate, and thus it may not be surprising to find a statistically insignificant effect in the first column. Note that in specification $B$, the reference category for the father's occupation is "skilled manual worker".

Taken together, the empirical results provide microeconomic evidence for a decline in social mobility among university graduates. Hence, aspirations for achieving a highlevel occupation and for moving up socially have, to some extent, remained unfulfilled among those from a lower socio-economic background. More specifically, the results suggest that for men from a less privileged background, the main hurdle for the old cohort was achieving a higher education. By contrast, for the young cohort, achieving a higher education has been only half the battle when it comes to securing a professional or formal occupation.

\subsubsection{Alternative Specifications}

Because the employment guarantee scheme applied not only to university graduates, but also to secondary school graduates, equation (6) is reestimated using the subsample of secondary and post-secondary graduates (see Table 9). Recall that, compared to university graduates, secondary school graduates of the old cohort were less likely to attain a professional occupation, but were almost equally likely to obtain a formal job (compare Figure 2). It thus seems plausible that, already for the old cohort, parental background mattered with respect to attaining a professional occupation. This was indeed the case: having a father working as a professional was associated with an increase in the son's likelihood of obtaining a professional occupation by 0.15 ; this is even more true for the young cohort (an additional increase in the likelihood by 0.13). As regards formal employment, however, the coefficient estimates are similar to those found for university graduates, in terms of both statistical significance and size. That is, parental background plays a role in obtaining a formal job only for the young cohort. Overall, these results suggest that as soon as employment opportunities in the private sector become limited, graduates from a high socio-economic background have an advantage over those from a low socio-economic background.

An alternative way to think about the decline in social mobility among the well- 
Table 9: Among Sons with Secondary Degrees and above: Relationship between Father's Occupation and Son's Occupation/Job (at Age 28).

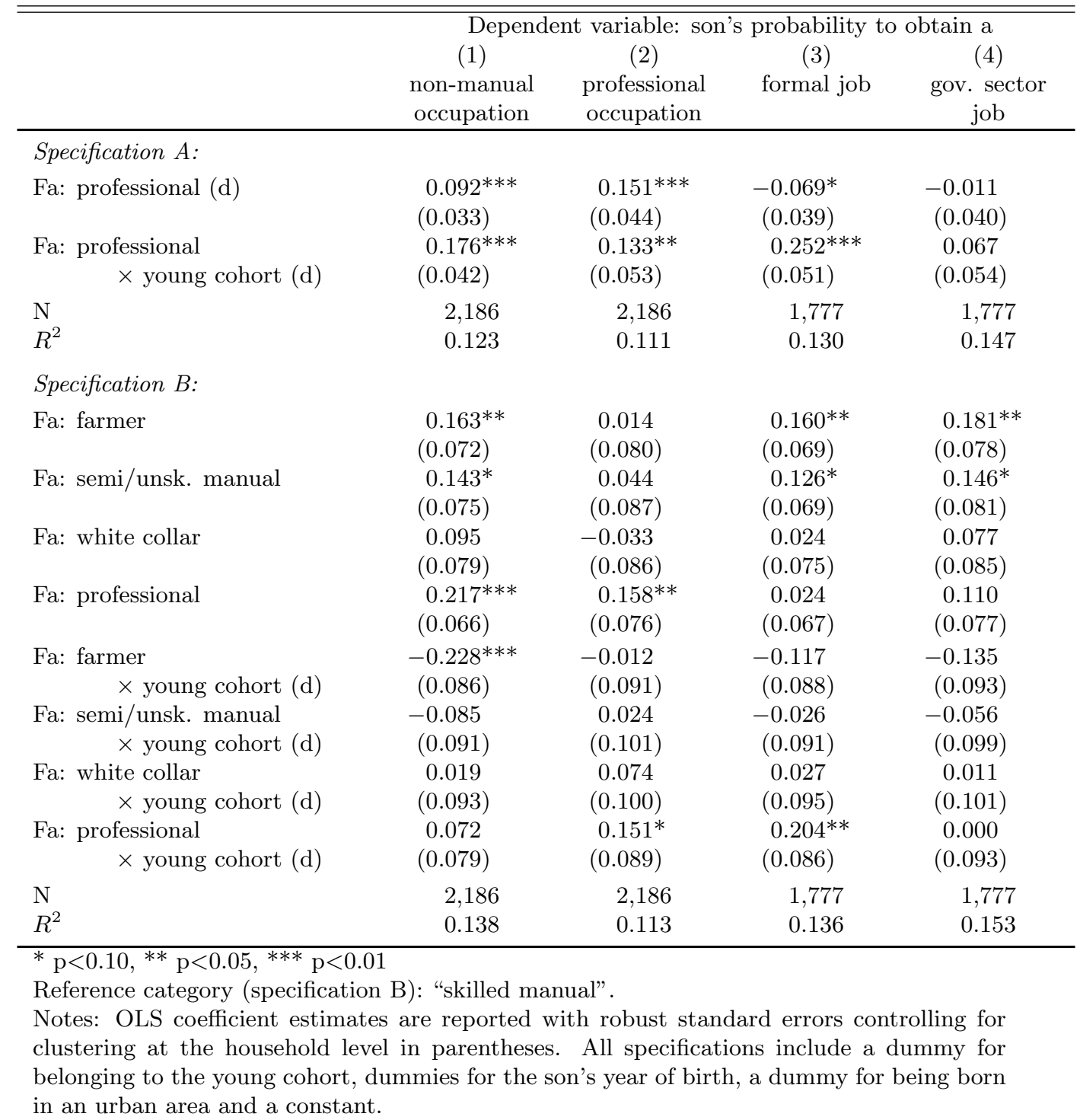

educated may be to hold parental background fixed, and to examine whether the returns to university education (in terms of occupational outcomes) have changed over time (see equation (7)). Estimation results in column (1) in Table 10 show that, conditional on the fathers not working in a professional occupation, the sons' (occupational) returns to university education have declined over time: the likelihood of obtaining a professional occupation has declined by 15 percentage points for secondary school graduates and by 
Table 10: Changes in the Occupational Returns to Schooling over Time.

\begin{tabular}{|c|c|c|c|}
\hline & $\begin{array}{l}\text { son's probability } \\
(1) \\
\text { Cond. on the father not } \\
\text { working as professional }\end{array}$ & $\begin{array}{l}\text { pendent variable: } \\
\text { obtain a professional occ } \\
\qquad(2) \\
\text { Cond. on the father } \\
\text { working as professional }\end{array}$ & $\begin{array}{l}\text { Ipation } \\
\qquad(3) \\
\text { Full sample }\end{array}$ \\
\hline Primary/preparatory degree & $\begin{array}{c}0.014 \\
(0.020)\end{array}$ & $\begin{array}{c}0.000 \\
(0.095)\end{array}$ & $\begin{array}{c}0.011 \\
(0.020)\end{array}$ \\
\hline Secondary degree & $\begin{array}{l}0.269^{* * *} \\
(0.034)\end{array}$ & $\begin{array}{l}0.258^{* * *} \\
(0.092)\end{array}$ & $\begin{array}{l}0.268^{* * *} \\
(0.034)\end{array}$ \\
\hline Post-secondary degree & $\begin{array}{l}0.749^{* * *} \\
(0.033)\end{array}$ & $\begin{array}{l}0.505^{* * *} \\
(0.073)\end{array}$ & $\begin{array}{l}0.751^{* * *} \\
(0.033)\end{array}$ \\
\hline $\begin{array}{c}\text { Primary/preparatory degree } \\
\times \text { young cohort }(\mathrm{d})\end{array}$ & $\begin{array}{c}-0.007 \\
(0.024)\end{array}$ & $\begin{array}{c}0.144 \\
(0.134)\end{array}$ & $\begin{array}{c}0.005 \\
(0.024)\end{array}$ \\
\hline $\begin{array}{l}\text { Secondary degree } \\
\quad \times \text { young cohort }(\mathrm{d})\end{array}$ & $\begin{array}{l}-0.148^{* * *} \\
(0.038)\end{array}$ & $\begin{array}{c}-0.034 \\
(0.114)\end{array}$ & $\begin{array}{l}-0.138^{* * *} \\
(0.038)\end{array}$ \\
\hline $\begin{array}{l}\text { Post-secondary degree } \\
\quad \times \text { young cohort }(\mathrm{d}) \\
\text { Fa: professional }(\mathrm{d})\end{array}$ & $\begin{array}{l}-0.159^{* * *} \\
(0.043)\end{array}$ & $\begin{array}{l}0.189^{* *} \\
(0.093)\end{array}$ & $\begin{array}{l}-0.151^{* * *} \\
(0.044) \\
0.181^{* * *} \\
(0.043)\end{array}$ \\
\hline $\begin{array}{l}\text { Primary/preparatory degree } \\
\times \text { Fa: prof }\end{array}$ & & & $\begin{array}{c}0.003 \\
(0.083)\end{array}$ \\
\hline $\begin{array}{l}\text { Secondary degree } \\
\times \text { Fa: prof }\end{array}$ & & & $\begin{array}{c}0.007 \\
(0.085)\end{array}$ \\
\hline $\begin{array}{l}\text { Post-secondary degree } \\
\times \text { Fa: prof }\end{array}$ & & & $\begin{array}{l}-0.202^{* * * *} \\
(0.064)\end{array}$ \\
\hline $\begin{array}{l}\text { Primary/preparatory degree } \\
\times \text { Fa: prof } \times \text { young cohort }\end{array}$ & & & $\begin{array}{c}0.043 \\
(0.106)\end{array}$ \\
\hline $\begin{array}{l}\text { Secondary degree } \\
\quad \times \text { Fa: prof } \times \text { young cohort }\end{array}$ & & & $\begin{array}{c}-0.019 \\
(0.086)\end{array}$ \\
\hline $\begin{array}{l}\text { Post-secondary degree } \\
\quad \times \text { Fa: prof } \times \text { young cohort }\end{array}$ & & & $0.193^{* * *}$ \\
\hline $\mathrm{N}$ & 3,154 & 855 & 4,009 \\
\hline$R^{2}$ & 0.376 & 0.294 & 0.408 \\
\hline
\end{tabular}

${ }^{*} \mathrm{p}<0.10,{ }^{* *} \mathrm{p}<0.05,{ }^{* * *} \mathrm{p}<0.01$

Reference category for the son's years of schooling: "no educational degree".

Notes: OLS coefficient estimates are reported with robust standard errors controlling for clustering at the household level in parentheses. All specifications include a dummy for belonging to the young cohort, dummies for the son's year of birth, a dummy for being born in an urban area and a constant.

16 percentage points for university graduates. In contrast, results in column (2) indicate that for their better-off counterparts, the returns to education actually increased. The fact that the returns to university education used to be comparatively high for those from a low socio-economic background illustrates that, essentially, without a university degree, these men had a negligible chance of attaining a professional occupation - in 
contrast to their better-off counterparts. Finally, column (3) confirms that for those who come from a lower socio-economic background the returns to university education declined relative to those who come from a high socio-economic background.

Finally, it could be that the expansion of the educational system allowed less able children from a low socio-economic background to gain a university education and that it is these kids who, eventually, end up in inferior occupations or jobs. Yet, the increase in private costs to public education, especially increasing expenses for private tutoring, together with the earlier finding that university education has remained exclusive, speak against such a scenario. If there is an ability discrepancy at all, it is more likely that university graduates from a low socio-economic background are, on average, "smarter" than their better-off counterparts.

\subsection{Sensitivity Analysis}

To examine the robustness of the estimates presented here for intergenerational educational and occupational mobility, the models for sons' years of schooling and sons' likelihood of attaining a professional occupation are reestimated, changing the cohort parameters of the old cohort to men born between 1951 and 1960 and to men born between 1949 and 1958. For the young cohort, the alternative cohort parameters are men born between 1970 and 1977 and men born between 1968 and 1975. Additionally, sons' current place of residence is used instead of residence at birth. The estimation results for intergenerational educational mobility are displayed in Table 16 in the Appendix and should be compared to the last three columns in Table 5. Overall, these results support the previous ones. As we would expect, the association between fathers' and sons' years of schooling is slightly stronger when the old cohort does not include men born in 1959 and 1960. Similarly, the reduction in the association between fathers' and sons' years of schooling is smaller if the young cohort does not include men born in 1976 and 1977. As for the alternative specification, restricting the old cohort to men born between 1949 and 1958 increases the association between the father having a post-secondary degree and the son's years of schooling, resulting in a significant decline in this association for the young cohort. Furthermore, at the lower tail of the distribution of fathers' educational attainment, the association between fathers' education and sons' education is stronger for men of the old cohort. Therefore, the models for the likelihood of the son obtaining a secondary school degree or better and of the son obtaining a post-secondary degree are reestimated (not reported here), but results are not qualitatively different.

With regard to the intergenerational occupational mobility estimates, alternative 
specifications additionally include comparing occupations of the sons at age 30 (instead of 28) and using the sons' current or first occupation in the case of an incomplete job history. OLS results are presented in Appendix Table 17 for the subsample of sons who achieved a post-secondary degree. Note that for clarity of exposition, results are shown only for sons attaining a professional occupation. Hence, these estimates are to be compared to the estimates shown in column (2) in Table 9. The results show that across all specifications, the father's occupation had essentially no "effect" on the son attaining a professional occupation for the old cohort, but it did have an effect for the young cohort. In some specifications, graduates of the young cohort whose fathers have a white-collar occupation are also more likely to hold a professional occupation than their older counterparts, i.e. not only those whose fathers have a professional occupation. Finally, it could be that among men of the young cohort, those from the lower ranks of society eventually do attain a high-level occupation, but that they require more time. In such a scenario, we should find that the association between the father and the son holding a professional occupation is lower when comparing the sons' occupational attainment at age 30. While this is indeed the case, the coefficient estimate is only slightly smaller (.334 compared to .368).

For further comparison, Table 18 in the Appendix shows the average marginal effects from estimating the equation (6) as a probit model. Overall, results are very similar to the OLS estimates. Additionally, average marginal effects for how fathers' and sons' occupations are related to each other for the full sample of sons, i.e. unconditional on father's educational attainment, are presented in Table 19. The upper and middle parts of the table show results for estimating the model separately for the old and the young cohort, while the lower part of the table shows the average marginal effects based on the full sample, including interaction terms. For the full sample, tests are performed to determine whether the average marginal effects differ significantly for men born in 19491960 compared to men born in 1968-1977. While there are some differences between the old and the young cohorts, few are significant. They are mostly related to the son's likelihood of working at a semi/unskilled manual occupation. Thus, more generally, immobility seems to have changed only marginally. Finally, Table 20 in the Appendix indicates that a similar pattern emerges if the model is estimated separately for sons born in rural and in urban areas. 


\section{Conclusions}

This is the first study to document the profound changes in intergenerational educational and economic mobility for an Arab country in the Middle East. It provides quantitative, microeconomic evidence for a decline in social mobility among the increasing ranks of well-educated youth in Egypt, which has created unfulfilled aspirations among those who come from the lower socio-economic strata. The fact that barriers to a university education have remained high across the two cohorts is to some degree contrary to the picture presented in the literature on the Islamic revival - namely, that access to a university education has increased. However, these barriers are also likely to have aggravated frustrations among university students from a lower socio-economic background.

It is important to note that the decline in job opportunities in the formal sector as well as the decline in real wages in the government sector has had other far-reaching social implications. Among other things, Egypt, and the Middle East more generally, has seen a strong delay in men's age at first marriage, despite the fact that pre-marital relationships have largely remained taboo. Men typically work for years in order to afford the costs associated with marriage, which not only include the costs for the wedding celebration but also for housing and electrical appliances (Singerman, 1995; Hoodfar, 1997; Assaad, Binzel and Gadallah, 2010). In addition to sufficiently high earnings, the bride's parents expect the groom to hold a "respectable" job. In part, this is linked to social status, but also, having a stable, formal job simply assures the bride's family that the groom is able to guarantee a certain standard of living in the future and that he is able to support a family. ${ }^{25}$ Consequently, despite the great value that family formation continues to play in the Middle East, only about 53\% of men aged 25-29 are married - the lowest figure compared to other developing regions (Mensch and Casterline, 2005).

Two sources of low social mobility in Egypt have been proposed in the literature reviewed earlier: personal connections and the financial resources necessary for acquiring the additional skills offered by the private education sector. The latter factor emphasizes the importance of public-school quality in providing equal opportunities when capital markets are imperfect, while personal connections are linked to the functioning of the labor market. The empirical analysis presented here provides some evidence for personal connections playing a significant role in the private sector. If personal or social connec-

\footnotetext{
${ }^{25}$ Women's increased educational attainment has put further pressure on the groom's side as the following quote from a university graduate illustrates: "I'm trying to get both, status and money; when you want to marry, you need both. If you tell the family of a girl you're interested in marrying that you have a government job, but you're only earning 70 pounds a month, they tell you to finish your tea and go home. And if you're just a plain taxi driver and the girl is educated, they also might not agree" (Wickham, 2002, p. 58).
} 
tions are based on kinship ties, they likely reinforce high economic persistence across generations. The empirical results further indicate that it is only when employment opportunities in the private sector become scarce that a graduate's parental background begins to play a role. Hence, in regard to Egypt - and presumably Middle Eastern countries more generally - the importance of personal connections seems to have been exacerbated by the fact that the dominance of the public sector and the high degree of regulation in the private sector have constrained the labor market's ability to absorb newly-skilled labor market entrants. Hence, contrary to empirical evidence for Latin America (Behrman, Gaviria and Székely, 2001; Dunn, 2007; Hertz et al., 2007), the overall high transmission of economic status across generations in Egypt seems not to be primarily driven by capital market imperfections, but by labor market inefficiencies. Therefore, aside from school quality, this paper has stressed the need to address labor market issues.

Education and labor market policies in the Arab world have had a devastating impact on many young people and have contributed to religious and political tensions throughout the region. The Middle East is a test case in how dangerous it can be to create aspirations among the young and their families by providing increased access to education without undertaking corresponding measures to strengthen the labor market. 


\section{References}

Aly, Hassan Y., and Michael P. Shields. 1996. "A Model of Temporary Migration: The Egyptian Case." International Migration, 34(3): 431-447.

Amer, Mona. 2009. "The Egyptian Youth Labor Market School-to-Work Transition, 1988-2006." In The Egyptian Labor Market Revisited. , ed. Ragui Assaad, Chapter 6, 177-218. Cairo, New York:The American University Cairo Press.

Assaad, Ragui. 1997. "The Effects of Public Sector Hiring and Compensation Policies on the Egyptian Labor Market." World Bank Economic Review, 11(1): 85-118.

Assaad, Ragui. 2007. "Institutions, Household Decisions, and Economic Growth in Egypt." In Explaining Gowth in the Middle East. , ed. Jeffrey B. Nugent and M. Hashem Pesaran, Chapter 13, 385-411. Amsterdam:Elsevier.

Assaad, Ragui. 2009. "Labor Supply, Employment, and Unemployment in the Egyptian Economy, 1988-2006." In The Egyptian Labor Market Revisited. , ed. Ragui Assaad, Chapter 1, 1-52. Cairo, New York:The American University Cairo Press.

Assaad, Ragui, and Fatma El Hamidi. 2009. "Women in the Egyptian Labor Market: An Analysis of Developments, 1988-2006." In The Egyptian Labor Market Revisited. , ed. Ragui Assaad, Chapter 7, 259-284. Cairo, New York:The American University Cairo Press.

Assaad, Ragui, Christine Binzel, and May Gadallah. 2010. "Transitions to Employment and Marriage Among Young Men in Egypt." Middle East Development Journal, 2(1): 39-88.

Barro, Robert, and Jong-Wha Lee. 2010. "A New Data Set of Educational Attainment in the World, 1950-2010." NBER Working Paper 15902.

Bayat, Asef. 2002. "Activism and Social Development in the Middle East." International Journal of Middle East Studies, 34(1): 1-28.

Becker, Gary S., and Nigel Tomes. 1986. "Human Capital and the Rise and Fall of Families." Journal of Labor Economics, 4(3).

Behrman, Jere R., Alejandro Gaviria, and Miguel Székely. 2001. "Intergenerational Mobility in Latin America." Inter-American Development Bank Research Department Working Paper 452.

Binder, Melissa, and Christopher Woodruff. 2002. "Inequality and Intergenerational Mobility in Schooling: The Case of Mexico." Economic Development and Cultural Change, 50(2): 249-267.

Björklund, Anders, and Markus Jäntti. 2000. "Intergenerational Mobility of SocioEconomic Status in Comparative Perspective." Nordic Journal of Political Economy, 26(1): 3-32. 
Campante, Filipe R., and Davin Chor. 2011. "“The People Want the Fall of the Regime": Schooling, Political Protest, and the Economy." HKS Faculty Research Working Paper RWP11-018.

Campante, Filipe R., and Davin Chor. forthcoming. "Schooling, Political Participation, and the Economy." Review of Economics and Statistics.

Carvalho, Jean-Paul. 2010. "A Theory of the Islamic Revival." mimeo.

Corak, Miles. 2004. Generational Income Mobility in North America and Europe. New York:Cambridge University Press.

Dhillon, Navtej, Paul Dyer, and Tarik Yousef. 2009. "Generation in Waiting: An Overview of School to Work and Family Formation Transitions." In Generation in Waiting. , ed. Navtej Dhillon and Tarik Yousef. Brookings Institution Press, Washington, D.C.

Dunn, Christopher. 2007. "The Intergenerational Transmission of Lifetime Earnings: Evidence from Brazil." The B.E. Journal of Economic Analysis $\&$ Policy, 7(2).

ELMPS. 2006. "Egypt Labor Market Panel Survey of 2006. Publicly Accessible Database, Economic Research Forum, Cairo, Egypt (www.erf.org.eg)."

Erikson, Robert, John H. Goldthorpe, and Lucienne Portocarero. 1983. "Intergenerational Class Mobility and the Convergence Thesis: England, France and Sweden." British Journal of Sociology, 34(3): 303-343.

Farah, Nadia R. 2009. Egypt's Political Economy: Power Relations in Development. Cairo; New York: American University in Cairo Press.

Ganzeboom, Harry B. G., and Donald J. Treiman. 1996. "Internationally Comparable Measures of Occupational Status for the 1988 International Standard Classification of Occupations." Social Science Research, 25(3): 201-239.

Grawe, Nathan D. 2004. "Intergenerational Mobility for Whom?" In Generational Income Mobility in North America and Europe., ed. Miles Corak. Cambridge:Cambridge University Press.

Grawe, Nathan D., and Casey B. Mulligan. 2002. "Economic Interpretations of Intergenerational Correlations." Journal of Economic Perspectives, 16(3): 45-58.

Handoussa, Heba. 1988. "The Burden of Public Sector Employment in Egypt." mimeo, Geneva: ILO.

Handoussa, Heba, and Nivine El Oraby. 2004. "Civil Service Wages and Reform: The Case of Egypt." The Egyptian Center for Economic Studies Working Paper 98.

Hanushek, Eric A., and Ludger Woessmann. 2007. "The Role of Education Quality for Economic Growth." World Bank Policy Research Working Paper 4122. 
Hanushek, Eric A., and Victor Lavy. 1994. "School Quality, Achievement Bias, and Dropout Behavior in Egypt." World Bank LSMS Working Paper 107.

Hargreaves, Eleanore. 1997. "The Diploma Disease in Egypt: Learning, Teaching and the Monster of the Secondary Leaving Certificate." Assessment in Education, 4(1): 161-176.

Heckman, James J., Lance J. Lochner, and Petra E. Todd. 2006. "Earnings Functions, Rates of Return and Treatment Effects: The Mincer Equation and Beyond." In Handbook of the Economics of Education. Vol. 1, , ed. Eric A Hanushek and Finis Welch, Chapter 7. Elsevier B.V.

Hertz, Tom, Mieke Meurs, and Sibel Selcuk. 2009. "The Decline in Intergenerational Mobility in Post-Socialism: Evidence from the Bulgarian Case." World Development, 37(3): 739-752.

Hertz, Tom, Tamara Jayasundera, Patrizio Piraino, Sibel Selcuk, Nicole Smith, and Alina Verashchagina. 2007. "The Inheritance of Educational Inequality: International Comparisons and Fifty-Year Trends." The B.E. Journal of Economic Analysis \& Policy, 7(2).

Hoodfar, Homa. 1997. Between Marriage and the Market - Intimate Politics and Survival in Cairo. Berkeley, CA:University of California Press.

ILO. 1991. "International Standard Classification of Occupations: ISCO-88." International Labor Office, Geneva:International Labour Organization (ILO).

Jensen, Robert. 2010. "The (Perceived) Returns to Education and the Demand for Schooling." Quarterly Journal of Economics, 2(125): 515-548.

Kandil, Magda E., and Mohammady Metwally. 1992. "Determinants of the Egyptian Labour Migration." International Migration, 30(1): 39-56.

Korayem, Karima. 1997. "Egypt's Economic Reform and Structural Adjustment Program (ERSAP)." The Egyptian Center for Economic Studies Working Paper 19.

Long, Jason, and Joseph Ferrie. 2007. "The Path to Convergence: Intergenerational Occupational Mobility in Britain and the US in Three Eras." Economic Journal, 117(519): 61-71.

Loury, Glenn C. 1981. "Intergenerational Transfers and the Distribution of Earnings." Econometrica, 49(4): 843-867.

Louw, Megan, Servaas van der Berg, and Derek Yu. 2007. "Convergence of a Kind: Educational Attainment and Intergenerational Social Mobility in South Africa." South African Journal of Economics, 75(3): 548-571.

Mazumdar, Dipak. 1989. "Microeconomic Issues of Labor Markets in Developing Countries: Analysis and Policy Implications." World Bank EDI Seminar Paper 40. 
Mensch, Barbara S., Susheela Singh, and John B. Casterline. 2005. "Trends in the Timing of First Marriage among Men and Women in the Developing World." In The Changing Transitions to Adulthood in Developing Countries: Selected Studies. , ed. Nelly P. Stromquist Cynthia B. Lloyd, Jere R. Behrman and Barney Cohen, 118-171. Washington, DC:National Academies Press.

Mookherjee, Dilip, and Debray Ray. 2002. "Contractual Structure and Wealth Accumulation." American Economic Review, 92(4): 818-849.

Morduch, Jonathan. 1995. "Income Smoothing and Consumption Smoothing." Journal of Economic Perspectives, 9(3): 103-114.

Nagi, Saad Z. 2001. Poverty in Egypt: Human Needs and Institutional Capacities. University Press of America, Inc. Lexington Books.

Ng, Irene. 2007. "Intergenerational Income Mobility in Singapore." The B.E. Journal of Economic Analysis 83 Policy, 7(2).

Nicoletti, Cheti, and John F. Ermisch. 2007. "Intergenerational Earnings Mobility: Changes across Cohorts in Britain." The B.E. Journal of Economic Analysis \& Policy, $7(2)$.

Population Council. 2010. "Survey of Young People in Egypt: Preliminary Report." The Population Counci.

Pritchett, Lant. 2001. "Where Has All the Education Gone?" The World Bank Economic Review, 15(3): 367-391.

Richards, Alan. 1992. "Higher Education in Egypt." World Bank Policy Research Working Paper 862.

Richards, Alan, and John Waterbury. 2008. A Political Economy of the Middle East. . 3rd ed., Boulder, Colo.:Westview Press.

Rosenzweig, Mark R., and Kenneth Wolpin. 1993. "Credit Market Constraints, Consumption Smoothing, and the Accumulation of Durable Production Assets in Lowincome Countries: Investments in Bullocks in India." Journal of Political Economy, 101(2): 223-244.

Salehi-Isfahani, Djavad. 2007. "Microeconomics of Growth in MENA: The Role of Households." In Explaining Gowth in the Middle East. , ed. Jeffrey B. Nugent and M Hashem Pesaran, Chapter 6, 159-194. Amsterdam:Elsevier.

Salehi-Isfahani, Djavad, Insan Tunali, and Ragui Assaad. 2009. "A Comparative Study of Returns to Education of Urban Men in Egypt, Iran, and Turkey." Middle East Development Journal, 1(2): 145-187.

Salmi, Jamil. 1990. "Vocational Education in Algeria, Egypt and Morocco: The Crisis and Its Lessons." Prospects, 20(1): 95-106. 
Schmidt, Peter, and Robert P. Strauss. 1975. "The Prediction of Occupation Using Multiple Logit Models." International Economic Review, 16(2): 471-486.

Sell, Ralph R. 1988. "Egyptian International Labor Migration and Social Processes: Toward Regional Integration." International Migration Review, 22(3): 87-108.

Shann, Mary H. 1992. "The Reform of Higher Education in Egypt." Higher Education, 24: $225-246$.

Singerman, Diana. 1995. Avenues of Participation: Family, Politics, and Networks in Urban Quarters of Cairo. Princeton:Princeton University Press.

Solon, Gary. 2002. "Cross-Country Differences in Intergenerational Earnings Mobility." Journal of Economic Perspectives, 16(3): 59-66.

Udry, Christopher. 1995. "Risk and Saving in Northern Nigeria." American Economic Review, 85(5): 1287-1300.

UNDP. 1998. "Egypt: Human Development Report 1997/98." Cairo:Institute of National Planning and UNDP.

UNDP. 2000. "Egypt: Human Development Report 1998/99." Cairo:Institute of National Planning and UNDP.

UN Population Division. 2009. "World Population Prospects: The 2008 Revision Population Database." Retrieved February 1, 2010, from http://esa.un.org/unpp/.

Valero-Gil, Jorge N., and Jose A. Tijerina-Guajardo. 2002. "Effects of Education on the Intergenerational Transmission of Labor Income in Mexico." Eastern Economic Journal, 28(3): 381-392.

Wickham, Carrie R. 2002. Mobilizing Islam: Religion, Activism and Social Change in Egypt. New York:Columbia University Press.

World Bank. 1991. "Egypt: Alleviating Poverty during Structural Adjustment." Washington, DC:The World Bank.

World Bank. 2004a. "Gender and Development in the Middle East and North Africa: Women in the Public Sphere." Washington, DC:The World Bank.

World Bank. 2004b. "Unlocking the Employment Potential in the Middle East and North Africa: Toward a New Social Contract." Washington, DC:The World Bank.

World Values Survey. 2009. "1981-2008 Official Aggregate v.20090901. World Values Survey Association (www.worldvaluessurvey.org). Aggregate File Producer: ASEP/JDS, Madrid." 


\section{A Construction of Occupational Categories}

The five occupational categories - professionals (i.e. higher and lower service workers), other white-collar (i.e. routine non-manual) workers, skilled manual laborers, semi/unskilled manual laborers and farmers - were constructed as follows. ${ }^{26}$ First, based on the codebook of the Central Agency for Public Mobilization and Statistics (CAPMAS), Egypt's National Statistical Bureau, the CAPMAS occupational codes were mapped to the ILO International Standard Classification of Occupations 1988 (ISCO-88; ILO, 1991) codes at the 3-digit level, the highest digit level available in the codebook. The major difference between the CAPMAS and the ISCO-88 occupational scheme is that CAPMAS adapted the ILO scheme to include further sub-categories - for instance, whether the individual is working in the private or public sector. The ISCO- 88 codes were then mapped to the "root" EGP classes based on the technique provided in Ganzeboom and Treiman (1996). ${ }^{27}$ In order to consider exceptions in the mapping scheme at the 4-digit level, occupational categories were traced in the CAPMAS codebook and assigned to the appropriate root EGP classes. Finally, the root EGP classes were collapsed to the five categories mentioned above; see Table 11. Given the high share of men working in agriculture in Egypt, farmers are kept in a category separate from other manual labor. Finally, note that large enterprise department managers in the field of agriculture are coded as professionals, not as farmers.

Table 12 shows how the different occupations are related to various job characteristics based on the current primary employment of men aged 20 to 65 in the 2006 cross section of the ELMPS06. In contrast to all other occupations, a relatively small share of farmers works for a wage. As expected, unpaid family work is much higher among farmers. Similarly, the share of employers varies strongly across occupations. Note that the sector of employment and the formality of the job refer to wage and salary workers only. In particular, professional occupations are associated with working in the government sector and with having a formal job, i.e. a job providing both social insurance and a work contract. For wage earners, average monthly earnings, including bonuses and other supplementary payments for regular workers, are displayed in Table $13 .^{28}$

\footnotetext{
${ }^{26}$ The construction of occupational categories was part of a joint research project with Marwan Khawaja.

${ }^{27}$ In contrast to the root EGP classes, the enhanced EGP scheme uses information about selfemployment and supervisory status in order to further differentiate between occupations.

${ }^{28}$ Since consumer price indices were not available for urban and rural areas, for comparability the sample is split up based on men's current area of residence. Using the exchange rate as of January 2006, 1 US dollar is equivalent to 5.7 Egyptian pounds.
} 
Table 11: Occupational Categories and Overall Distribution.

\begin{tabular}{lcl}
\hline \hline Occupation & $\begin{array}{l}\text { Overall } \\
\text { share }\end{array}$ & Most numerous ISCO-88 titles \\
\hline Professional & 27.10 & $\begin{array}{l}\text { [Large Enterprise] Department Managers; Primary and Pre-Primary } \\
\text { Education Teaching Professionals; Physical and Engineering } \\
\text { Science Technicians }\end{array}$ \\
White collar & 15.74 & $\begin{array}{l}\text { Housekeeping and Restaurant Services Workers; Shop Salespersons } \\
\text { and Demonstrators }\end{array}$ \\
Skilled manual & 20.72 & $\begin{array}{l}\text { Building Frame, etc. Trades Workers; Building Finishers, etc. } \\
\text { Trades Workers; Wood Treaters, Cabinet-Makers, etc. Trades Workers } \\
\text { Semi/Unskilled } \\
\text { manual }\end{array}$ \\
$\begin{array}{l}\text { Farmers } \\
\text { Total }\end{array}$ & 15.55 & $\begin{array}{l}\text { Hotor-Vehicle Drivers; Protective Service Workers; Domestic, etc. } \\
\text { Helpers and Launderers }\end{array}$ \\
\hline
\end{tabular}

Notes: Based on men aged 20-65 (N=8,193). Source: ELMPS06.

Table 12: Employment Status, Sector of Employment and Job Formality by Occupation.

\begin{tabular}{lcccccc}
\hline \hline & \multicolumn{3}{c}{ Employment Status $(\mathrm{N}=8,193)$} & Share of public & $\begin{array}{c}\text { Share of } \\
\text { formal jobs } \\
(\mathrm{N}=5,540)\end{array}$ \\
\hline Professional & 71.96 & 16.97 & 10.67 & 0.41 & 76.02 & 88.84 \\
White collar & 82.18 & 2.92 & 10.98 & 3.92 & 56.30 & 64.00 \\
Skilled manual & 74.71 & 11.61 & 11.53 & 2.14 & 22.70 & 20.86 \\
Semi/Unskilled manual & 88.27 & 3.35 & 7.69 & 0.69 & 49.63 & 41.06 \\
Farmers & 28.69 & 44.34 & 6.88 & 20.09 & 37.48 & 5.18 \\
\hline Total & 67.64 & 17.24 & 9.64 & 5.47 & 56.21 & 51.42 \\
\hline
\end{tabular}

Notes: Questions about the sector of employment and job formality were administered to wage workers only. A job is defined as "formal" if the worker has both a work contract and social insurance. Based on men aged 20-65 (ELMPS06). 
Table 13: Average Monthly Earnings and Hourly Wage (in L.E., Egyptian Pound) by Occupation.

\begin{tabular}{lcrrrrr}
\hline \hline Occupation & $\begin{array}{c}\text { Average } \\
\text { monthly earnings* }\end{array}$ & Std. Dev. & $\mathrm{N}$ & $\begin{array}{c}\text { Hourly } \\
\text { wage }\end{array}$ & Std. Dev. & N \\
\hline Rural Areas & & & & & & \\
Professional & 669.27 & $1,307.34$ & 574 & 4.04 & 8.16 & 571 \\
White collar & 547.68 & $1,849.91$ & 528 & 3.08 & 11.13 & 524 \\
Skilled manual & 445.24 & 280.25 & 661 & 2.51 & 2.17 & 640 \\
Semi/Unskilled manual & 557.32 & $1,250.15$ & 655 & 2.53 & 5.57 & 647 \\
Farmers & 294.91 & 114.18 & 442 & 1.82 & 0.89 & 437 \\
Total & 511.55 & $1,168.45$ & 2,860 & 2.82 & 6.73 & 2,818 \\
Urban Areas & & & & & \\
Professional & & & & & & \\
White collar & & & & & & \\
Skilled manual & 116.28 & $1,921.00$ & 1,017 & 6.11 & 10.31 & 1,010 \\
Semi/Unskilled manual & 623.63 & 908.22 & 531 & 3.11 & 4.50 & 524 \\
Farmers & 623.57 & 924.92 & 601 & 3.26 & 5.25 & 590 \\
Total & 562.17 & 676.13 & 469 & 2.58 & 2.89 & 464 \\
\hline
\end{tabular}

*For wage workers with a regular income (permanent or temporary) bonus and other supplementary payments are included. For wage workers with an irregular income it refers to monetary income and income in kind. Using the exchange rate of January 2006, 1 US dollar is equivalent to 5.7 Egyptian pounds (L.E.).

Notes: Based on men aged 20-65 living in rural/urban areas (ELMPS06). 


\section{B Mobility Tables}

Table 14: Mobility Tables for Fathers' and Sons' Educational Attainment. 1949-1960 Cohort $(\mathrm{N}=1,858)$

\begin{tabular}{llrrrrr}
\hline \hline & & \multicolumn{5}{c}{ Son's education } \\
& & \multicolumn{1}{c}{$(1)$} & \multicolumn{1}{c}{$(2)$} & \multicolumn{1}{c}{$(3)$} & \multicolumn{1}{c}{$(4)$} & Total \\
\hline \multirow{3}{*}{ Father's } & (1) No degree & 42.78 & 15.29 & 15.13 & 10.29 & 83.49 \\
education & (2) Primary/preparatory degree & 1.10 & 1.17 & 2.29 & 4.05 & 8.61 \\
& (3) Secondary degree & 0.20 & 0.27 & 1.21 & 2.48 & 4.17 \\
& (4) Above secondary degree & 0.00 & 0.06 & 0.46 & 3.23 & 3.74 \\
\hline \multirow{5}{*}{ Father's } & Total & 44.07 & 16.79 & 19.09 & 20.05 & 100.00 \\
& & \multicolumn{5}{c}{ Son's education } \\
& & $(1)$ & $(2)$ & $(3)$ & $(4)$ & Total \\
\hline \hline & & 19.42 & 14.67 & 27.11 & 13.87 & 75.07 \\
& & 0.68 & 1.52 & 4.61 & 4.40 & 11.22 \\
& (1) No degree & 0.06 & 0.33 & 2.69 & 3.88 & 6.96 \\
& (3) Srimary/preparatory degree & $(\mathrm{N}=2,631)$ & & \\
& (4) Above secondary degree & 0.03 & 0.10 & 0.68 & 5.94 & 6.75 \\
\hline & Total degree & 20.20 & 16.62 & 35.09 & 28.10 & 100.00
\end{tabular}

Source: ELMPS06.

Table 15: Mobility Tables for Fathers' and Sons' Occupational Attainment. 1949-1960 Cohort $(\mathrm{N}=1,617)$

\begin{tabular}{|c|c|c|c|c|c|c|c|}
\hline & & \multicolumn{6}{|c|}{ Son's occupation } \\
\hline & & (1) & $(2)$ & $(3)$ & $(4)$ & $(5)$ & Total \\
\hline \multirow{9}{*}{$\begin{array}{l}\text { Father's } \\
\text { occupation }\end{array}$} & (1) Farmer & 24.35 & 5.18 & 4.40 & 5.75 & 7.63 & 47.31 \\
\hline & (2) Semi/Unskilled manual & 0.62 & 2.59 & 2.56 & 2.49 & 3.51 & 11.77 \\
\hline & (3) Skilled manual & 0.49 & 1.97 & 4.61 & 1.34 & 2.62 & 11.04 \\
\hline & (4) White collar & 0.50 & 1.80 & 3.44 & 3.06 & 3.43 & 12.23 \\
\hline & (5) Professional & 0.38 & 1.40 & 2.28 & 4.07 & 9.51 & 17.65 \\
\hline & Total & 26.35 & 12.95 & 17.28 & 16.71 & 26.70 & 100.00 \\
\hline & \multicolumn{7}{|c|}{ 1968-1977 Cohort $(\mathrm{N}=2,320)$} \\
\hline & & \multicolumn{6}{|c|}{ Son's occupation } \\
\hline & & (1) & $(2)$ & $(3)$ & $(4)$ & $(5)$ & Total \\
\hline \multirow{6}{*}{$\begin{array}{l}\text { Father's } \\
\text { occupation }\end{array}$} & (1) Farmer & 14.28 & 4.52 & 7.79 & 3.63 & 5.24 & 35.46 \\
\hline & (2) Semi/Unskilled manual & 0.96 & 4.35 & 3.13 & 2.51 & 3.88 & 14.83 \\
\hline & (3) Skilled manual & 0.38 & 2.31 & 5.67 & 2.16 & 2.67 & 13.20 \\
\hline & (4) White collar & 1.18 & 2.50 & 3.79 & 3.98 & 4.27 & 15.72 \\
\hline & (5) Professional & 0.63 & 1.81 & 3.08 & 3.71 & 11.56 & 20.79 \\
\hline & Total & 17.43 & 15.49 & 23.46 & 16.00 & 27.62 & 100.00 \\
\hline
\end{tabular}

Source: ELMPS06. 


\section{Additional Results (Section 6.2)}

(a) 1949-1960 Cohort

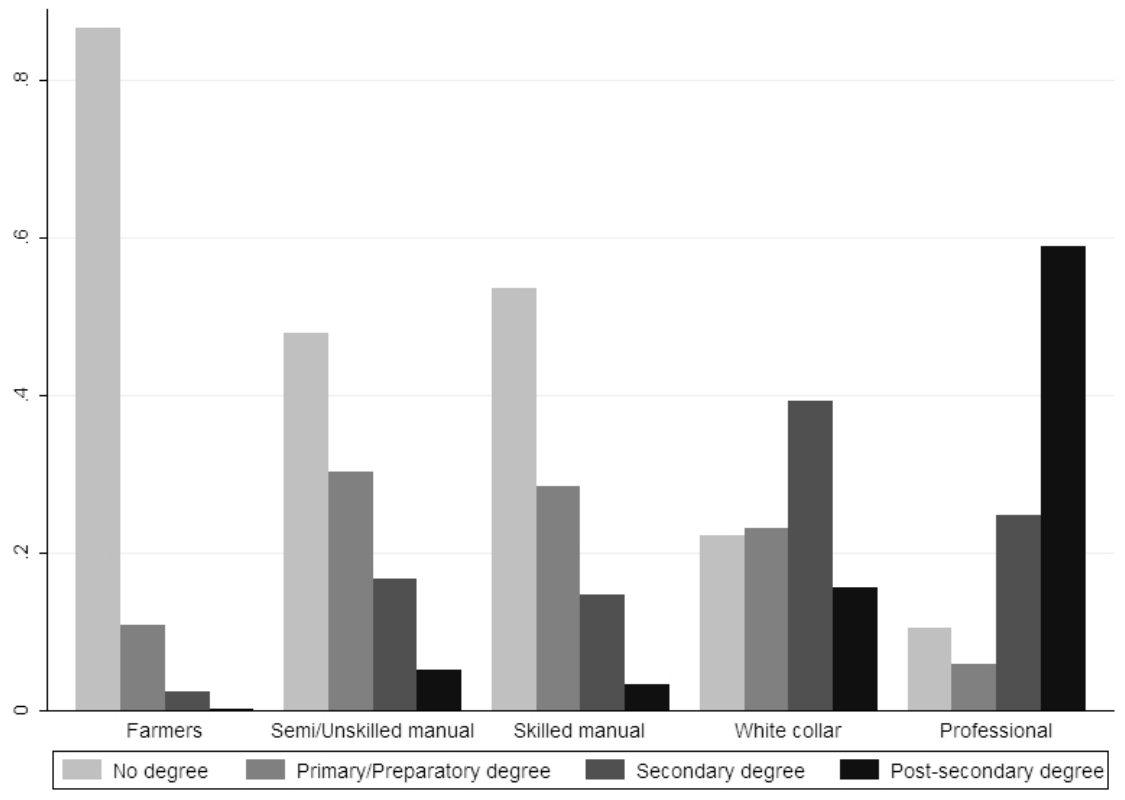

(b) 1968-1977 Cohort

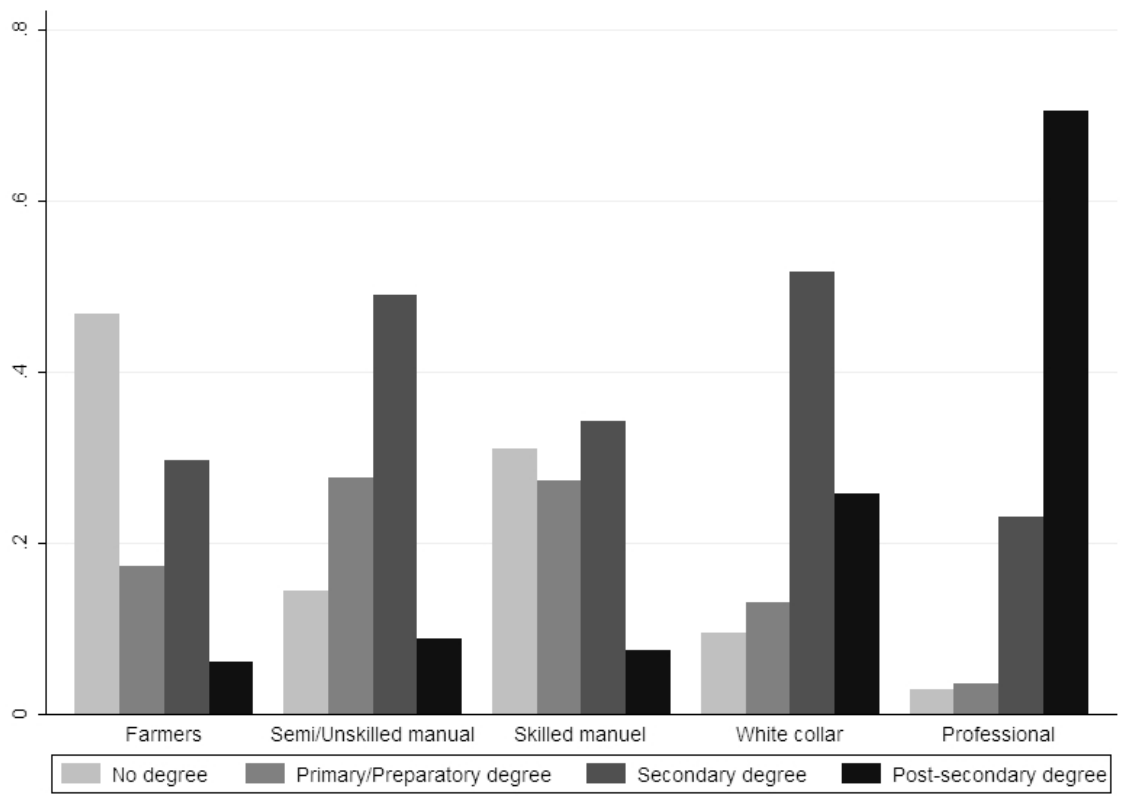

Source: ELMPS06.

Figure 4: Distribution of Educational Attainment across Occupations. 


\section{Results from the Sensitivity Analysis (Section 6.3)}

Table 16: Robustness Analysis for Intergenerational Educational Mobility Estimates.

\begin{tabular}{|c|c|c|c|c|c|c|}
\hline & \multicolumn{6}{|c|}{ Years of schooling } \\
\hline & $1951-60$ & $1949-58$ & $1970-77$ & $1968-75$ & Rural & Urban \\
\hline Fa: years of schooling & $\begin{array}{l}0.659^{* * *} \\
(0.030)\end{array}$ & $\begin{array}{l}0.735^{* * *} \\
(0.029)\end{array}$ & $\begin{array}{l}0.698^{* * *} \\
(0.027)\end{array}$ & $\begin{array}{l}0.698^{* * *} \\
(0.027)\end{array}$ & $\begin{array}{l}0.840^{* * *} \\
(0.074)\end{array}$ & $\begin{array}{l}0.533^{* * *} \\
(0.029)\end{array}$ \\
\hline $\begin{array}{l}\text { Fa: years of schooling } \\
\quad \times \text { young cohort }(\mathrm{d})\end{array}$ & $\begin{array}{l}-0.219^{* * *} \\
(0.033)\end{array}$ & $\begin{array}{l}-0.295^{* * *} \\
(0.033)\end{array}$ & $\begin{array}{l}-0.263^{* * *} \\
(0.031)\end{array}$ & $\begin{array}{l}-0.247^{* * *} \\
(0.032)\end{array}$ & $\begin{array}{c}-0.344^{* * *} \\
(0.081)\end{array}$ & $\begin{array}{l}-0.184^{* * *} \\
(0.034)\end{array}$ \\
\hline $\begin{array}{l}\mathrm{N} \\
R^{2}\end{array}$ & $\begin{array}{c}4,261 \\
0.2118\end{array}$ & $\begin{array}{c}4,207 \\
0.2447\end{array}$ & $\begin{array}{c}4,145 \\
0.2427\end{array}$ & $\begin{array}{c}3,902 \\
0.2254\end{array}$ & $\begin{array}{c}1,979 \\
0.2095\end{array}$ & $\begin{array}{c}2,570 \\
0.2218\end{array}$ \\
\hline \multicolumn{7}{|l|}{ Alternative specification: } \\
\hline Fa: no degree & $\begin{array}{l}-7.370^{* * *} \\
(0.556)\end{array}$ & $\begin{array}{l}-8.017^{* * *} \\
(0.548)\end{array}$ & $\begin{array}{l}-7.879^{* * *} \\
(0.492)\end{array}$ & $\begin{array}{l}-7.879^{* * *} \\
(0.492)\end{array}$ & $\begin{array}{l}-9.459^{* * *} \\
(0.926)\end{array}$ & $\begin{array}{l}-5.876^{* * *} \\
(0.556)\end{array}$ \\
\hline Fa: primary/preparatory degree & $\begin{array}{c}-1.598^{* *} \\
(0.746)\end{array}$ & $\begin{array}{r}-1.197 \\
(0.766)\end{array}$ & $\begin{array}{c}-1.684^{* *} \\
(0.689)\end{array}$ & $\begin{array}{c}-1.684^{* *} \\
(0.689)\end{array}$ & $\begin{array}{c}-2.699^{* *} \\
(1.303)\end{array}$ & $\begin{array}{l}-1.230 \\
(0.778)\end{array}$ \\
\hline Fa: post-secondary degree & $\begin{array}{l}2.264^{* * *} \\
(0.634)\end{array}$ & $\begin{array}{l}2.769^{* * *} \\
(0.610)\end{array}$ & $\begin{array}{l}2.249^{* * *} \\
(0.566)\end{array}$ & $\begin{array}{l}2.249^{* * *} \\
(0.566)\end{array}$ & $\begin{array}{c}1.309 \\
(1.832)\end{array}$ & $\begin{array}{l}2.364^{* * *} \\
(0.591)\end{array}$ \\
\hline $\begin{array}{l}\text { Fa: no degree } \\
\quad \times \text { young cohort }(\mathrm{d})\end{array}$ & $\begin{array}{l}2.146^{* * *} \\
(0.617)\end{array}$ & $\begin{array}{l}2.793^{* * *} \\
(0.609)\end{array}$ & $\begin{array}{l}2.683^{* * *} \\
(0.570)\end{array}$ & $\begin{array}{l}2.592^{* * *} \\
(0.581)\end{array}$ & $\begin{array}{l}3.357^{* * *} \\
(1.075)\end{array}$ & $\begin{array}{l}1.954^{* * *} \\
(0.636)\end{array}$ \\
\hline $\begin{array}{c}\text { Fa: primary/preparatory degree } \\
\times \text { young cohort }(\mathrm{d})\end{array}$ & $\begin{array}{c}-0.238 \\
(0.821)\end{array}$ & $\begin{array}{c}-0.639 \\
(0.840)\end{array}$ & $\begin{array}{r}-0.159 \\
(0.779)\end{array}$ & $\begin{array}{c}0.128 \\
(0.798)\end{array}$ & $\begin{array}{r}-0.128 \\
(1.503)\end{array}$ & $\begin{array}{c}-0.169 \\
(0.857)\end{array}$ \\
\hline $\begin{array}{l}\text { Fa: post-secondary degree } \\
\quad \times \text { young cohort }(\mathrm{d})\end{array}$ & $\begin{array}{r}-0.673 \\
(0.692)\end{array}$ & $\begin{array}{c}-1.178^{*} \\
(0.670)\end{array}$ & $\begin{array}{c}-0.727 \\
(0.634)\end{array}$ & $\begin{array}{r}-0.700 \\
(0.659)\end{array}$ & $\begin{array}{c}0.180 \\
(1.942)\end{array}$ & $\begin{array}{r}-0.634 \\
(0.663)\end{array}$ \\
\hline $\mathrm{N}$ & 4,261 & 4,207 & 4,145 & 3,902 & 1,979 & 2,570 \\
\hline$R^{2}$ & 0.2129 & 0.2465 & 0.2447 & 0.2280 & 0.2081 & 0.2240 \\
\hline
\end{tabular}

$* \mathrm{p}<0.10,{ }^{* *} \mathrm{p}<0.05, * * * \mathrm{p}<0.01$

Notes: OLS results are reported with standard errors controlling for clustering at the household level in parentheses. All specifications include dummies for the son's year of birth and a constant. The reference category for father's education in the alternative specification is "secondary degree". 


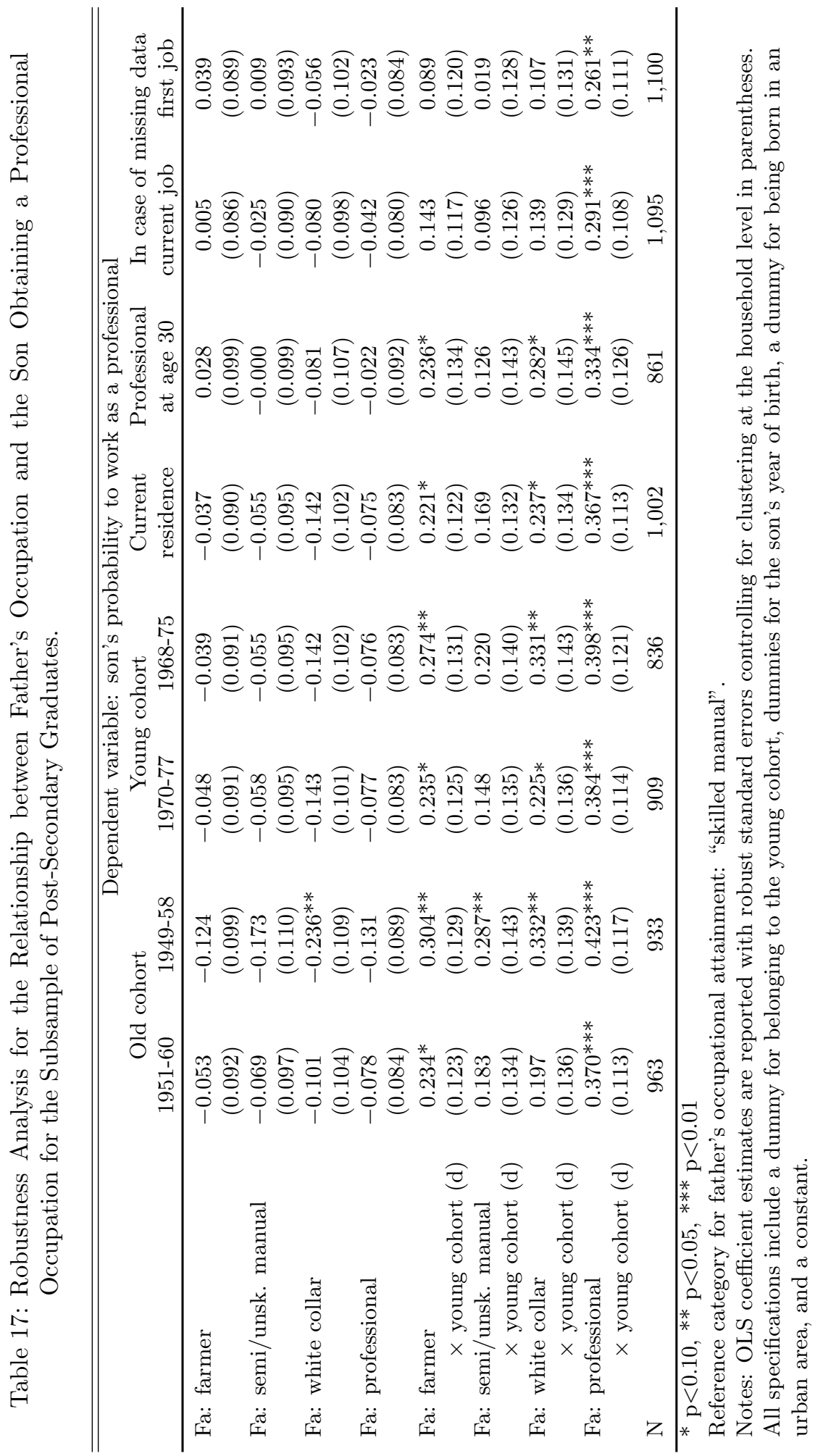


Table 18: Among Sons with Secondary Degrees and above: Relationship between Father's Occupation and Son's Occupation/Job (at Age 28).

\begin{tabular}{|c|c|c|c|c|}
\hline & $\begin{array}{c}\text { De } \\
(1) \\
\text { non-manual } \\
\text { occupation }\end{array}$ & $\begin{array}{c}\text { variable: son's } \\
(2) \\
\text { professional } \\
\text { occupation } \\
\end{array}$ & $\begin{array}{l}\text { ability to obt } \\
\qquad \begin{array}{l}(3) \\
\text { formal job }\end{array}\end{array}$ & $\begin{array}{l}(4) \\
\text { gov. sector } \\
\text { job }\end{array}$ \\
\hline & \multicolumn{4}{|c|}{ (i) Sample of sons with post-secondary degrees } \\
\hline Fa (old cohort): farmer & $\begin{array}{c}0.132 \\
(0.112)\end{array}$ & $\begin{array}{r}-0.029 \\
(0.101)\end{array}$ & $\begin{array}{c}0.033 \\
(0.073)\end{array}$ & $\begin{array}{c}0.118 \\
(0.087)\end{array}$ \\
\hline Fa (old cohort): semi/unsk. manual & $\begin{array}{c}0.120 \\
(0.108)\end{array}$ & $\begin{array}{r}-0.050 \\
(0.106)\end{array}$ & $\begin{array}{c}0.061 \\
(0.076)\end{array}$ & $\begin{array}{c}0.090 \\
(0.086)\end{array}$ \\
\hline Fa (old cohort): white collar & $\begin{array}{c}0.112 \\
(0.121)\end{array}$ & $\begin{array}{r}-0.172 \\
(0.116)\end{array}$ & $\begin{array}{r}-0.073 \\
(0.093)\end{array}$ & $\begin{array}{c}0.003 \\
(0.091)\end{array}$ \\
\hline Fa (old cohort): professional & $\begin{array}{c}0.165 \\
(0.113)\end{array}$ & $\begin{array}{r}-0.074 \\
(0.096)\end{array}$ & $\begin{array}{r}-0.078 \\
(0.078)\end{array}$ & $\begin{array}{c}0.046 \\
(0.081)\end{array}$ \\
\hline $\mathrm{Fa}$ (young cohort): farmer & $\begin{array}{c}0.052 \\
(0.067)\end{array}$ & $\begin{array}{l}0.173^{* *} \\
(0.079)\end{array}$ & $\begin{array}{c}0.119 \\
(0.087)\end{array}$ & $\begin{array}{l}0.215^{* *} \\
(0.087)\end{array}$ \\
\hline Fa (young cohort): semi/unsk. manual & $\begin{array}{c}0.107 \\
(0.068)\end{array}$ & $\begin{array}{c}0.112 \\
(0.084)\end{array}$ & $\begin{array}{l}0.162^{* *} \\
(0.088)\end{array}$ & $\begin{array}{l}0.220^{* *} \\
(0.091)\end{array}$ \\
\hline Fa (young cohort): white collar & $\begin{array}{l}0.145^{* *} \\
(0.067)\end{array}$ & $\begin{array}{c}0.092 \\
(0.080)\end{array}$ & $\begin{array}{c}0.058 \\
(0.089)\end{array}$ & $\begin{array}{c}0.123 \\
(0.087)\end{array}$ \\
\hline Fa (young cohort): professional & $\begin{array}{l}0.207^{* * *} \\
(0.064)\end{array}$ & $\begin{array}{l}0.273^{* * *} \\
(0.072)\end{array}$ & $\begin{array}{l}0.254^{* * *} \\
(0.082)\end{array}$ & $\begin{array}{c}0.133^{*} \\
(0.077)\end{array}$ \\
\hline \multirow[t]{2}{*}{$\begin{array}{l}\mathrm{N} \\
\text { pseudo } R^{2}\end{array}$} & $\begin{array}{c}1,002 \\
0.0935\end{array}$ & $\begin{array}{c}1,002 \\
0.0884\end{array}$ & $\begin{array}{c}870 \\
0.1204\end{array}$ & $\begin{array}{c}870 \\
0.1056\end{array}$ \\
\hline & \multicolumn{4}{|c|}{ (ii) Sample of sons with secondary degrees and above } \\
\hline Fa (old cohort): farmer & $\begin{array}{r}0.135^{*} \\
(0.078)\end{array}$ & $\begin{array}{r}-0.024 \\
(0.078)\end{array}$ & $\begin{array}{c}0.117 \\
(0.080)\end{array}$ & $\begin{array}{l}0.193^{* *} \\
(0.080)\end{array}$ \\
\hline Fa (old cohort): semi/unsk. manual & $\begin{array}{r}0.147^{*} \\
(0.082)\end{array}$ & $\begin{array}{c}0.035 \\
(0.086)\end{array}$ & $\begin{array}{c}0.122 \\
(0.084)\end{array}$ & $\begin{array}{c}0.146^{*} \\
(0.082)\end{array}$ \\
\hline Fa (old cohort): white collar & $\begin{array}{c}0.102 \\
(0.084)\end{array}$ & $\begin{array}{r}-0.037 \\
(0.085)\end{array}$ & $\begin{array}{c}0.016 \\
(0.087)\end{array}$ & $\begin{array}{c}0.078 \\
(0.083)\end{array}$ \\
\hline Fa (old cohort): professional & $\begin{array}{l}0.238^{* * *} \\
(0.083)\end{array}$ & $\begin{array}{c}0.159^{* *} \\
(0.076)\end{array}$ & $\begin{array}{c}0.026 \\
(0.078)\end{array}$ & $\begin{array}{c}0.110 \\
(0.077)\end{array}$ \\
\hline $\mathrm{Fa}$ (young cohort): farmer & $\begin{array}{c}-0.103^{* *} \\
(0.048)\end{array}$ & $\begin{array}{c}-0.034 \\
(0.045)\end{array}$ & $\begin{array}{c}-0.012 \\
(0.055)\end{array}$ & $\begin{array}{c}0.062 \\
(0.053)\end{array}$ \\
\hline Fa (young cohort): semi/unsk. manual & $\begin{array}{c}0.051 \\
(0.052)\end{array}$ & $\begin{array}{c}0.059 \\
(0.051)\end{array}$ & $\begin{array}{c}0.086 \\
(0.058)\end{array}$ & $\begin{array}{c}0.090 \\
(0.056)\end{array}$ \\
\hline Fa (young cohort): white collar & $\begin{array}{l}0.106^{* *} \\
(0.050)\end{array}$ & $\begin{array}{c}0.032 \\
(0.049)\end{array}$ & $\begin{array}{c}0.045 \\
(0.056)\end{array}$ & $\begin{array}{c}0.087 \\
(0.054)\end{array}$ \\
\hline Fa (young cohort): professional & $\begin{array}{l}0.284^{* * *} \\
(0.046)\end{array}$ & $\begin{array}{l}0.308^{* * *} \\
(0.045)\end{array}$ & $\begin{array}{l}0.223^{* * *} \\
(0.052)\end{array}$ & $\begin{array}{l}0.106^{* *} \\
(0.051)\end{array}$ \\
\hline $\begin{array}{l}\mathrm{N} \\
\text { pseudo } R^{2}\end{array}$ & $\begin{array}{c}2,186 \\
0.1106\end{array}$ & $\begin{array}{c}2,186 \\
0.0830\end{array}$ & $\begin{array}{c}1,777 \\
0.1100\end{array}$ & $\begin{array}{c}1,777 \\
0.1216\end{array}$ \\
\hline
\end{tabular}

$* \mathrm{p}<0.10,{ }^{* *} \mathrm{p}<0.05, * * * \mathrm{p}<0.01$

Reference category for father's occupational attainment: "skilled manual".

Notes: Average marginal effects are reported taking into account the categorical nature of father's occupation and, where needed, the interaction terms with the dummy for belonging to the young cohort. Standard errors controlling for clustering at the household level are reported in parentheses. All specifications include a dummy for belonging to the young cohort, dummies for the son's year of birth and a constant. 
Table 19: Multinomial Logit Results for Son's Occupational Attainment (at Age 28).

\begin{tabular}{|c|c|c|c|c|c|}
\hline & \multicolumn{5}{|c|}{ Dependent variable: son's occupational attainment } \\
\hline & Farmers & $\begin{array}{c}\text { Semi/Unsk. } \\
\text { manual }\end{array}$ & $\begin{array}{l}\text { Skilled } \\
\text { manual }\end{array}$ & $\begin{array}{l}\text { White } \\
\text { collar }\end{array}$ & Professionals \\
\hline & \multicolumn{5}{|c|}{ 1949-1960 Cohort $\left(\mathrm{N}=1,642 ;\right.$ pseudo $\left.R^{2}=0.1402\right)$} \\
\hline Fa: farmer & $\begin{array}{l}0.465^{* * *} \\
(0.028)\end{array}$ & $\begin{array}{c}-0.083^{* *} \\
(0.035)\end{array}$ & $\begin{array}{c}-0.323^{* * *} \\
(0.040)\end{array}$ & $\begin{array}{c}0.003 \\
(0.028)\end{array}$ & $\begin{array}{r}-0.063^{*} \\
(0.035)\end{array}$ \\
\hline Fa: semi/unskilled manual & $\begin{array}{c}0.006 \\
(0.027)\end{array}$ & $\begin{array}{c}0.024 \\
(0.044)\end{array}$ & $\begin{array}{c}-0.198^{* * *} \\
(0.049)\end{array}$ & $\begin{array}{l}0.092^{* *} \\
(0.040)\end{array}$ & $\begin{array}{c}0.077 \\
(0.049)\end{array}$ \\
\hline Fa: white collar & $\begin{array}{c}-0.005 \\
(0.024)\end{array}$ & $\begin{array}{c}-0.046 \\
(0.042)\end{array}$ & $\begin{array}{c}-0.139^{* * *} \\
(0.053)\end{array}$ & $\begin{array}{l}0.132^{* * *} \\
(0.040)\end{array}$ & $\begin{array}{c}0.058 \\
(0.047)\end{array}$ \\
\hline \multirow[t]{2}{*}{ Fa: professional } & $\begin{array}{c}-0.025 \\
(0.021)\end{array}$ & $\begin{array}{c}-0.115^{* * *} \\
(0.037)\end{array}$ & $\begin{array}{c}-0.287^{* * *} \\
(0.044)\end{array}$ & $\begin{array}{l}0.110^{* * *} \\
(0.036)\end{array}$ & $\begin{array}{l}0.316^{* * *} \\
(0.045)\end{array}$ \\
\hline & \multicolumn{5}{|c|}{ 1968-1977 Cohort $\left(\mathrm{N}=2,379 ;\right.$ pseudo $\left.R^{2}=0.1049\right)$} \\
\hline Fa: farmer & $\begin{array}{l}0.373^{* * *} \\
(0.022)\end{array}$ & $\begin{array}{c}-0.047^{*} \\
(0.028)\end{array}$ & $\begin{array}{c}-0.207^{* * *} \\
(0.035)\end{array}$ & $\begin{array}{c}-0.062^{* *} \\
(0.028)\end{array}$ & $\begin{array}{c}-0.057^{* *} \\
(0.029)\end{array}$ \\
\hline Fa: semi/unskilled manual & $\begin{array}{r}0.037^{*} \\
(0.019)\end{array}$ & $\begin{array}{l}0.113^{* * *} \\
(0.037)\end{array}$ & $\begin{array}{l}-0.219^{* * *} \\
(0.038)\end{array}$ & $\begin{array}{c}0.003 \\
(0.033)\end{array}$ & $\begin{array}{c}0.066^{*} \\
(0.037)\end{array}$ \\
\hline Fa: white collar & $\begin{array}{l}0.046^{* * *} \\
(0.018)\end{array}$ & $\begin{array}{c}-0.020 \\
(0.033)\end{array}$ & $\begin{array}{c}-0.185^{* * *} \\
(0.039)\end{array}$ & $\begin{array}{l}0.090^{* *} \\
(0.035)\end{array}$ & $\begin{array}{l}0.069^{* *} \\
(0.035)\end{array}$ \\
\hline Fa: professional & $\begin{array}{c}0.002 \\
(0.014)\end{array}$ & $\begin{array}{c}-0.089^{* * * *} \\
(0.028)\end{array}$ & $\begin{array}{c}-0.279^{* * *} \\
(0.035)\end{array}$ & $\begin{array}{c}0.015 \\
(0.032)\end{array}$ & $\begin{array}{l}0.350^{* * * *} \\
(0.035)\end{array}$ \\
\hline & \multicolumn{5}{|c|}{ Full sample $\left(\mathrm{N}=4,021 ;\right.$ pseudo $\left.R^{2}=0.1234\right)$} \\
\hline Fa (old cohort): farmer & $\begin{array}{l}0.469^{* * *} \\
(0.050)\end{array}$ & $\begin{array}{c}-0.140^{* *} \\
(0.055)\end{array}$ & $\begin{array}{c}-0.246^{* * *} \\
(0.048)\end{array}$ & $\begin{array}{c}-0.008 \\
(0.032)\end{array}$ & $\begin{array}{r}-0.076^{*} \\
(0.040)\end{array}$ \\
\hline Fa (old cohort): semi/unsk. manual & $\begin{array}{c}0.003 \\
(0.028)\end{array}$ & $\begin{array}{c}0.013 \\
(0.057)\end{array}$ & $\begin{array}{c}-0.156^{* * *} \\
(0.046)\end{array}$ & $\begin{array}{l}0.082^{* *} \\
(0.041)\end{array}$ & $\begin{array}{c}0.058 \\
(0.048)\end{array}$ \\
\hline Fa (old cohort): white collar & $\begin{array}{c}-0.007 \\
(0.026)\end{array}$ & $\begin{array}{c}-0.073 \\
(0.057)\end{array}$ & $\begin{array}{c}-0.106^{* *} \\
(0.046)\end{array}$ & $\begin{array}{l}0.133^{* * *} \\
(0.044)\end{array}$ & $\begin{array}{c}0.053 \\
(0.048)\end{array}$ \\
\hline $\mathrm{Fa}$ (old cohort): professional & $\begin{array}{c}-0.028 \\
(0.024)\end{array}$ & $\begin{array}{c}-0.175^{* * *} \\
(0.057)\end{array}$ & $\begin{array}{c}-0.215^{* * *} \\
(0.048)\end{array}$ & $\begin{array}{l}0.112^{* * *} \\
(0.042)\end{array}$ & $\begin{array}{l}0.307^{* * *} \\
(0.050)\end{array}$ \\
\hline Fa (young cohort): farmer & $\begin{array}{l}0.345^{* * *} \\
(0.037)\end{array}$ & $\begin{array}{c}-0.032 \\
(0.023)\end{array}$ & $\begin{array}{c}-0.219^{* * *} \\
(0.039)\end{array}$ & $\begin{array}{r}-0.051^{*} \\
(0.027)\end{array}$ & $\begin{array}{r}-0.043 \\
(0.029)\end{array}$ \\
\hline Fa (young cohort): semi/unsk. manual & $\begin{array}{l}0.037^{* *} \\
(0.018)\end{array}$ & $\begin{array}{l}0.098^{* * *} \\
(0.032)\end{array}$ & $\begin{array}{l}-0.230^{* * *} \\
(0.040)\end{array}$ & $\begin{array}{c}0.014 \\
(0.032)\end{array}$ & $\begin{array}{l}0.082^{* *} \\
(0.037)\end{array}$ \\
\hline Fa (young cohort): white collar & $\begin{array}{c}0.043^{* *} \\
(0.017)\end{array}$ & $\begin{array}{c}-0.012 \\
(0.026)\end{array}$ & $\begin{array}{c}-0.199^{* * *} \\
(0.040)\end{array}$ & $\begin{array}{l}0.092^{* * *} \\
(0.034)\end{array}$ & $\begin{array}{l}0.076^{* *} \\
(0.035)\end{array}$ \\
\hline Fa (young cohort): professional & $\begin{array}{c}0.003 \\
(0.012)\end{array}$ & $\begin{array}{c}-0.066^{* * *} \\
(0.023)\end{array}$ & $\begin{array}{c}-0.314^{* * *} \\
(0.038)\end{array}$ & $\begin{array}{c}0.022 \\
(0.031)\end{array}$ & $\begin{array}{l}0.355^{* * * *} \\
(0.037)\end{array}$ \\
\hline
\end{tabular}

${ }^{*} \mathrm{p}<0.10,{ }^{* *} \mathrm{p}<0.05,{ }^{* * *} \mathrm{p}<0.01$

Reference category for father's occupational attainment: "skilled manual".

Notes: Average marginal effects are reported taking into account the categorical nature of father's occupation and, for the full sample, the interaction terms with the dummy for belonging to the young cohort. Standard errors controlling for clustering at the household level are reported in parentheses. All specifications include a dummy for belonging to the young cohort and dummies for the son's year of birth and a constant. 
Table 20: Multinomial Logit Results for Son's Occupational Attainment (at Age 28) - Rural versus Urban Areas.

\begin{tabular}{|c|c|c|c|c|c|}
\hline & \multicolumn{5}{|c|}{ Dependent variable: son's occupational attainment } \\
\hline & Farmers & $\begin{array}{c}\text { Semi/Unsk. } \\
\text { manual }\end{array}$ & $\begin{array}{l}\text { Skilled } \\
\text { manual }\end{array}$ & $\begin{array}{l}\text { White } \\
\text { collar }\end{array}$ & Professionals \\
\hline & \multicolumn{5}{|c|}{ Rural areas $\left(\mathrm{N}=1,856 ;\right.$ pseudo $\left.R^{2}=0.1053\right)$} \\
\hline $\mathrm{Fa}$ (old cohort): farmers & $\begin{array}{l}0.406^{* * *} \\
(0.077)\end{array}$ & $\begin{array}{c}-0.263^{* * *} \\
(0.096)\end{array}$ & $\begin{array}{c}-0.169^{* * *} \\
(0.065)\end{array}$ & $\begin{array}{c}0.027 \\
(0.045)\end{array}$ & $\begin{array}{c}-0.001 \\
(0.058)\end{array}$ \\
\hline Fa (old cohort): semi/unsk. manual & $\begin{array}{c}0.003 \\
(0.094)\end{array}$ & $\begin{array}{r}-0.191^{*} \\
(0.109)\end{array}$ & $\begin{array}{r}-0.131^{*} \\
(0.069)\end{array}$ & $\begin{array}{l}0.167^{* *} \\
(0.080)\end{array}$ & $\begin{array}{c}0.152^{*} \\
(0.091)\end{array}$ \\
\hline Fa (old cohort): white collar & $\begin{array}{c}-0.056 \\
(0.087)\end{array}$ & $\begin{array}{r}-0.197^{*} \\
(0.111)\end{array}$ & $\begin{array}{c}-0.085 \\
(0.069)\end{array}$ & $\begin{array}{l}0.239^{* * *} \\
(0.092)\end{array}$ & $\begin{array}{c}0.099 \\
(0.086)\end{array}$ \\
\hline Fa (old cohort): professional & $\begin{array}{r}-0.149^{*} \\
(0.081)\end{array}$ & $\begin{array}{c}-0.276^{* *} \\
(0.113)\end{array}$ & $\begin{array}{c}-0.164^{* *} \\
(0.068)\end{array}$ & $\begin{array}{l}0.271^{* * *} \\
(0.092)\end{array}$ & $\begin{array}{l}0.318^{* * *} \\
(0.098)\end{array}$ \\
\hline Fa (young cohort): farmers & $\begin{array}{l}0.306^{* * *} \\
(0.049)\end{array}$ & $\begin{array}{r}-0.037 \\
(0.039)\end{array}$ & $\begin{array}{c}-0.221^{* * *} \\
(0.063)\end{array}$ & $\begin{array}{c}0.015 \\
(0.029)\end{array}$ & $\begin{array}{c}-0.063 \\
(0.048)\end{array}$ \\
\hline Fa (young cohort): semi/unsk. manual & $\begin{array}{c}0.069^{*} \\
(0.039)\end{array}$ & $\begin{array}{l}0.130^{* *} \\
(0.057)\end{array}$ & $\begin{array}{c}-0.248^{* * *} \\
(0.073)\end{array}$ & $\begin{array}{c}0.063 \\
(0.042)\end{array}$ & $\begin{array}{c}-0.014 \\
(0.057)\end{array}$ \\
\hline \multirow{3}{*}{ Fa (young cohort): professional } & $\begin{array}{l}0.068^{* *} \\
(0.035)\end{array}$ & $\begin{array}{c}0.007 \\
(0.047)\end{array}$ & $\begin{array}{l}-0.211^{* * *} \\
(0.074)\end{array}$ & $\begin{array}{l}0.152^{* * *} \\
(0.052)\end{array}$ & $\begin{array}{c}-0.017 \\
(0.055)\end{array}$ \\
\hline & $\begin{array}{c}0.025 \\
(0.033)\end{array}$ & $\begin{array}{c}-0.081^{*} \\
(0.042)\end{array}$ & $\begin{array}{c}-0.270^{* * *} \\
(0.076)\end{array}$ & $\begin{array}{c}0.047 \\
(0.043)\end{array}$ & $\begin{array}{l}0.279^{* * *} \\
(0.073)\end{array}$ \\
\hline & \multicolumn{5}{|c|}{ Urban areas $\left(\mathrm{N}=2,165 ;\right.$ pseudo $\left.R^{2}=0.0959\right)$} \\
\hline $\mathrm{Fa}$ (old cohort): farmers & $\begin{array}{l}0.189^{* *} \\
(0.079)\end{array}$ & $\begin{array}{c}0.029 \\
(0.067)\end{array}$ & $\begin{array}{c}-0.254^{* * *} \\
(0.062)\end{array}$ & $\begin{array}{c}0.046 \\
(0.050)\end{array}$ & $\begin{array}{c}-0.011 \\
(0.062)\end{array}$ \\
\hline Fa (old cohort): semi/unsk. manual & $\begin{array}{c}-0.002 \\
(0.003)\end{array}$ & $\begin{array}{c}0.100 \\
(0.061)\end{array}$ & $\begin{array}{l}-0.171^{* * *} \\
(0.059)\end{array}$ & $\begin{array}{c}0.048 \\
(0.048)\end{array}$ & $\begin{array}{c}0.026 \\
(0.057)\end{array}$ \\
\hline Fa (old cohort): white collar & $\begin{array}{c}0.009 \\
(0.009)\end{array}$ & $\begin{array}{c}-0.021 \\
(0.059)\end{array}$ & $\begin{array}{c}-0.123^{* *} \\
(0.060)\end{array}$ & $\begin{array}{c}0.088^{*} \\
(0.048)\end{array}$ & $\begin{array}{c}0.047 \\
(0.056)\end{array}$ \\
\hline Fa (old cohort): professional & $\begin{array}{c}0.013 \\
(0.009)\end{array}$ & $\begin{array}{c}-0.120^{* *} \\
(0.058)\end{array}$ & $\begin{array}{c}-0.253^{* * *} \\
(0.063)\end{array}$ & $\begin{array}{c}0.057 \\
(0.045)\end{array}$ & $\begin{array}{l}0.303^{* * *} \\
(0.056)\end{array}$ \\
\hline Fa (young cohort): farmers & $\begin{array}{l}0.332^{* * *} \\
(0.082)\end{array}$ & $\begin{array}{c}-0.031 \\
(0.036)\end{array}$ & $\begin{array}{c}-0.219^{* * *} \\
(0.062)\end{array}$ & $\begin{array}{c}-0.100^{* *} \\
(0.043)\end{array}$ & $\begin{array}{c}0.019 \\
(0.051)\end{array}$ \\
\hline Fa (young cohort): semi/unsk. manual & $\begin{array}{c}0.001 \\
(0.012)\end{array}$ & $\begin{array}{c}0.071^{*} \\
(0.037)\end{array}$ & $\begin{array}{c}-0.208^{* * *} \\
(0.048)\end{array}$ & $\begin{array}{r}-0.020 \\
(0.043)\end{array}$ & $\begin{array}{l}0.156^{* * *} \\
(0.047)\end{array}$ \\
\hline Fa (young cohort): white collar & $\begin{array}{c}0.017 \\
(0.019)\end{array}$ & $\begin{array}{r}-0.030 \\
(0.032)\end{array}$ & $\begin{array}{c}-0.182^{* * *} \\
(0.048)\end{array}$ & $\begin{array}{c}0.049 \\
(0.044)\end{array}$ & $\begin{array}{l}0.146^{* * *} \\
(0.045)\end{array}$ \\
\hline Fa (young cohort): professional & $\begin{array}{c}-0.006 \\
(0.010)\end{array}$ & $\begin{array}{c}-0.063^{* *} \\
(0.029)\end{array}$ & $\begin{array}{c}-0.314^{* * *} \\
(0.046)\end{array}$ & $\begin{array}{c}-0.002 \\
(0.041)\end{array}$ & $\begin{array}{l}0.384^{* * *} \\
(0.042)\end{array}$ \\
\hline
\end{tabular}

${ }^{*} \mathrm{p}<0.10,{ }^{* *} \mathrm{p}<0.05,{ }^{* * *} \mathrm{p}<0.01$

Reference category for father's occupational attainment: "skilled manual".

Notes: Average marginal effects are reported taking into account the categorical nature of father's occupation and the interaction terms with the dummy for belonging to the young cohort. Standard errors controlling for clustering at the household level are reported in parentheses. All specifications include a dummy for belonging to the young cohort and dummies for the son's year of birth and a constant. 